\title{
FINANCING DisPUTES: THIRD-PARTY FUNDING IN LITIGATION AND ARBITRATION
}

\author{
RACHEL HOWIE* AND GEOFF MOYSA ${ }^{* *}$
}

\begin{abstract}
Third-party funding is an arrangement where an entity with no prior interest in the merits of a dispute provides funding to a party involved in the dispute. Traditionally, this funding was specifically to assist the party to the dispute by financing its legal fees and costs and could be obtained in a number of ways, such as through insurance or loans from financial institutions. Third-party funding has seen significant growth and an increase in sophistication in recent years, resulting in a departure from this traditional model concurrent with the rise of commercial litigation funders whose entire business is providing non-recourse investment in disputes. This article explores both the changes in models of third-party funding - which can include some or all of: (1) paying for legal fees and disbursements, (2) indemnifying against the risk of an adverse costs order, (3) stepping in to provide security for costs, (4) providing working capital or portfolio funding for bundles of claims, and (5) the rise of institutional third-party financing in Canada. In particular, this article will explore some of the specific applications of third-party funding to the energy industry, including "David and Goliath" claims, claims involving state asset expropriation, and the use of funding as a tool for risk allocation in asset sales.
\end{abstract}

This article will also discuss the development and current state of the legal framework and case law in Canada with respect to third-party funding, along with third-party funding across different contexts and types of disputes. This includes the evolution of the law of maintenance and champerty and a discussion of key legal and ethical issues engaged by third-party funding arrangements including confidentiality, privilege, disclosure, conflicts of interest, and control of the dispute.

\section{TABLE OF ConTents}

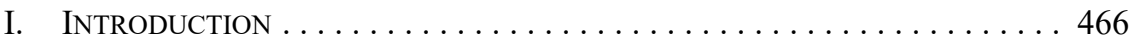

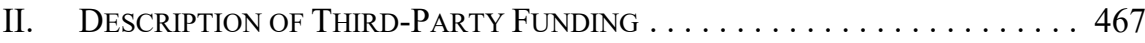

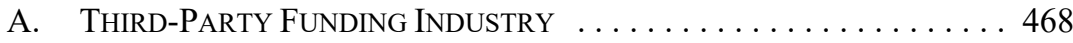

B. Litigation Funding VERSUS LitigAtion INSURANCE . . . . . . . . 470

III. REASONS FOR THIRD-PARTY Funding AND Funding Structures . . . . 470

A. Why Parties May SeEk Third-Party Funding . . . . . . . . . 470

B. Different Funding Structures: ExAmPles . . . . . . . . . . 472

IV. The Funding AgreEMENT $\ldots \ldots \ldots \ldots \ldots \ldots \ldots \ldots \ldots \ldots \ldots$

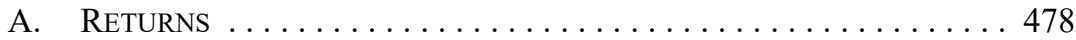

B. PRIORITY OF RETURNS . . . . . . . . . . . . . . . . . . . . . . . 479

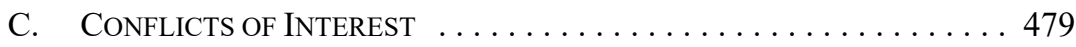

D. Control, Termination, and Settlement . . . . . . . . . 480

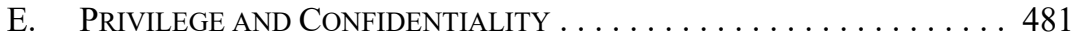

F. Disclosure of Funding AgreEMENTS . . . . . . . . . . 483

G. Adverse Costs And SECURITy For COSTS . . . . . . . . . 483

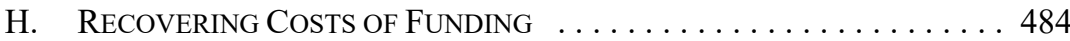

* $\quad$ Partner, Dentons Canada LLP, Calgary, Alberta.

** Investment Manager and Legal Counsel, Bentham IMF, Toronto, Ontario. The authors would like to thank Elizabeth Allum, student-at-law at Dentons Canada LLP, for her research and assistance in the preparation of this article. Any opinions expressed herein are those of the authors for the purposes of this article and do not reflect the views of either Dentons Canada LLP or Bentham IMF. 


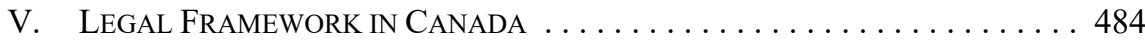

A. MAINTENANCE AND CHAMPERTY $\ldots \ldots \ldots \ldots \ldots \ldots \ldots \ldots . \ldots . \ldots 48$

B. Class Action Litigation . . . . . . . . . . . . . . . . . . . . . . . . 487

C. Commercial Litigation . . . . . . . . . . . . . . . . . . . . . . 489

D. InSOLVENCY LITIGATION . . . . . . . . . . . . . . . . . . . . 490

VI. FUNDING IN ARBITRAL PROCEEDINGS . . . . . . . . . . . . . . . . . . . . . . 491

A. InTERNATIONAL ARBITRATION . . . . . . . . . . . . . . 492

B. Domestic ARBITRATION . . . . . . . . . . . . . . . . . . 497

VII. Choosing a Funder And Negotiating a Funding Agreement . . . . . 499

A. Choosing a Funder . . . . . . . . . . . . . . . . . . . . . . . . . . 499

B. EARly Process AND Due Diligence . . . . . . . . . . . . . . . . 499

C. Negotiating the Funding AgreEMEnt . . . . . . . . . . . . . . . 500

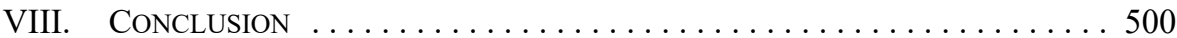

\section{INTRODUCTION}

The concept of a non-party to a dispute providing funding or resources to a party involved in a dispute is not new. Contingency fee arrangements, financial institution loans, corporate financing, before-the-event (BTE) litigation insurance, ${ }^{1}$ after-the-event (ATE) litigation insurance, ${ }^{2}$ and inter-corporate funding are all traditional methods by which a non-party provides funding or resources so that a party could pursue its claim or defence in a dispute. ${ }^{3}$ The key distinguishing feature of modern (institutional) dispute funding is that such funding is provided by an entity whose sole business is the financing of disputes. Taken together, traditional and modern funding represent different types of third-party funding (TPF) available to disputants.

In its modern form, TPF has moved from assisting a disadvantaged disputant into something tantamount to corporate finance "with increasingly diverse and sophisticated options becoming available." "As a result, it is possible to think about disputes, and interests in a dispute, in a fundamentally different way. As noted by one provider of TPF:

Litigation can be financed - just like any other corporate expense. Yet most corporations still pay for legal costs out of pocket, and that has a profoundly negative financial impact: Reducing operating profits,

BTE litigation insurance is purchased before litigation arises, and covers the costs of that litigation These costs often include fees of solicitors, barristers, and expert witnesses; court fines and fees; and any legal costs awarded to the other side. See Ingrid Sapona, "Legal Expense Insurance" (March 2018), online: CIP Society <insuranceinstitute.ca/en/cipsociety/information-services/advantage-monthly/0318legal-expense-insurance>.

2 ATE litigation insurance protects individuals against their opponent's adverse costs and their own disbursements, should the case fail. See Clubine v Paniagua, 2018 BCSC 1076 at para 27 (the ATE insurance would cover the "defendant's disbursements and costs from the date of the offer if costs were awarded against the plaintiff, and would also pay for the plaintiff's disbursements incurred but not awarded from the date of the offer").

3 Christopher P Bogart, "Third-Party Financing of International Arbitration" (2017) 2 Belgian Rev Arbitration 315. See also Jonas von Goeler, Third-Party Funding in International Arbitration and Its Impact on Procedure (Alphen aan den Rijn, The Netherlands: Kluwer Law International, 2016) at $52-56$.

4 International Council for Commercial Arbitration, Report of the ICCA-Queen Mary Task Force on Third-Party Funding in International Arbitration (The Hague: ICCA, 2018) at 37, online: $<$ arbitrationicca.org/media/10/40280243154551/icca_reports_4_tpf_final_for_print_5_april.pdf> [ICCA-QMUL Report]. 
impacting publicly reported earnings, and thus valuation. Litigation finance removes this problem by shifting the cost and risk of pursuing high-value litigation off corporate balance sheets. ${ }^{5}$

The entities now taking advantage of TPF are increasingly doing so as a means "to manage risk, to reduce legal budgets, take the cost of pursuing arbitration off-balance sheet, or to pursue other business priorities instead of allocating resources to financing"6 a dispute. In some cases, they could afford to pursue the claim, and bear the risk of a loss, but do not wish to assume this risk.

Around the turn of the century, professional commercial dispute was a very small industry in select jurisdictions. ${ }^{7}$ What began as a very small industry in select jurisdictions around the turn of the century has shown marked growth over the last decade. ${ }^{8}$ As of April 2018, the global industry of professional institutional funders was estimated to have in excess of US\$10 billion (CDN\$13 billion) in capital to invest in litigation and arbitration. ${ }^{9}$

Recent studies in the area of TPF have highlighted the many varieties available and legal impacts that can result from nuances in how the term "third-party funding" is defined. ${ }^{10}$ This article will begin by providing an overview of TPF, including the types of TPF commonly available. This will be followed by a discussion of common funding structures for institutional funding, and given the relatively novel nature of modern TPF, we will discuss certain key aspects of the funding agreement, followed by what is known with respect to the legal framework in Canada for TPF in litigation and arbitration. This article will conclude with comments on the funding process for institutional third-party funders, how to choose a funder, and how to negotiate a funding agreement.

\section{DESCRIPTION OF THIRD-PARTY FUNDING}

In a typical institutional litigation funding transaction, the funder (who is not a party to the litigation) enters into a litigation funding agreement (LFA) with the party seeking funding to pay all or part of that party's litigation costs in return for a fee or a share of the recovery.

Burford Capital, “Business Solutions,”online: [web.archive.org/web/20190410194407/burfordcapital. $\mathrm{com} /$ what-we-do/for-businesses].

$6 \quad$ ICCA-QMUL Report, supra note 4 at 20

7 IMF Bentham Limited, an Australian company, was the first funder to be publicly listed when it went public on the ASX in 2001. See Oliver Gayner, Tom Glasgow \& Nathan Landis, "Dispute Funding and the Energy Sector" in Ronnie King, ed, Arbitration in the International Energy Industry (Surrey, UK: Globe Law and Business, 2019) 245, online: <imf.com.au/docs/default-source/site-documents/arbit ration-in-the-international-energy-industry extract.pdf $>$. 8 von Goeler, supra note 3 at 74-75. IMF Bentham, for example, now has a global presence with offices
in Australia, Singapore, Hong Kong, London, the United States, and Canada and has recovered AUD $\$ 2.3$ billion (CDN\$2.15 billion) from disputes, of which over AUD $\$ 1.4$ billion (CDN\$1.3 billion) has been returned to claimants in accordance with funding agreements. Their current portfolio is reported to contain 80 investments - or investments in 80 disputes - for a total estimated value of over AUD \$3.4 billion (CDN\$3.1 billion).

9 ICCA-QMUL Report, supra note 4, n 30. See also Burford Capital, a global finance firm with over US\$3 billion committed to the legal market (Burford Capital, "Why Burford," online: <burfordcapital. com/about-burford/why-burford/>). See also Uliana Cooke, "Market Trends and Legal Issues in ThirdParty Funding," Global Arbitration Review (8 August 2018), online: <globalarbitrationreview.com/ article/1172791/market-trends-and-legal-issues-in-third-party-funding $>$.

10 ICCA-QMUL Report, supra note 4. See also British Columbia Law Institute, "Study Paper on Financing Litigation" (2017) BCLI Study Paper No 9, online: <bcli.org/wordpress/wp-content/uploads/2017/ 10/2017-10-04-BCLI-Study-Paper-on-Financing-Litigation-PUBLICATION-COPY-rev.pdf> [BCLI Study]. 
The covered litigation costs typically include lawyers' fees along with expert witness fees and other disbursements. The share of the recovery is a portion of the amount ultimately obtained and is either specified or arrived at through a mathematical formula. Under the LFA, the funder may also provide working capital to the disputing party and the funder will usually agree to pay any court-ordered costs, including any security for costs. In this type of funding, the amounts payable to a funder depend on the successful resolution of the claim. A successful outcome for these purposes may be a monetary award made in favour of the claimant or a settlement of the claim that involves a financial recovery by the claimant. If the claim fails, the funder receives nothing and, typically (unlike a traditional loan), remains liable for any fees due to the claimant's lawyer and other disbursements paid, together with any adverse costs that it has agreed to pay and that are incurred during the term of the funding agreement.

Any type of commercial claim or business dispute may be suitable for funding. As will be discussed in further detail below, certain disputes within the energy industry may lend themselves particularly well to third-party funding, including "David and Goliath" claims that pit smaller companies against better capitalized defendants; claims involving the expropriation of a company's chief revenue-generating asset; claims within the insolvent estates of energy companies; and claims that are being sold in, or carved out of, asset sales.

\section{A. The ThiRd-PARTy Funding INDUSTRY}

The TPF industry originated in Australia as a tool within insolvency proceedings in the 1990s. ${ }^{11}$ Legislative reforms first allowed a form of financing that enabled insolvency practitioners to finance litigation within the insolvency by characterizing it as company property. ${ }^{12}$ Class action lawsuits were also introduced in Australia in the early 1990s. However, contingency fees were not (and are still not) permitted in Australia. ${ }^{13}$ In addition, Australia is subject to a harsh "loser pays" costs regime where it is not uncommon for an unsuccessful party to be ordered to pay 80 percent of the successful party's fees. ${ }^{14}$ Australia's nascent TPF industry began to expand into class actions, and assumed the fees and adverse costs risks that otherwise made many meritorious class proceedings unviable. However, the use of TPF did not become more widespread until a 2006 decision of the Australian High Court which held that LFAs served a legitimate purpose and were not an abuse of process or contrary to public policy. ${ }^{15}$

In the United Kingdom, a pair of unrelated innovations combined to create the regulatory conditions conducive to TPF. First, in the late 1960s, criminal prohibitions and tort liability

$11 \quad$ ICCA-QMUL Report, ibid at 18.

Lake Whillans, "The History and Evolution of Litigation Finance," Above the Law (27 January 2017), online: <abovethelaw.com/2017/01/the-history-and-evolution-of-litigation-finance/>.

13 Stuart Clark \& Christina Harris, "The Push to Reform Class Action Procedure in Australia: Evolution or Revolution?" (2008) 32:3 Melbourne UL Rev 775 at 788. The Australian Law Reform Commission (ALRC) has recently recommended the limited introduction of contingency fees in Australia. The ALRC's report in this regard was tabled in Australian Parliament by the Attorney General in January 2019 (Austl, Commonwealth, Australian Law Reform Commission, Inquiry into Class Action Proceedings and Third-Party Litigation Funders (Discussion Paper No 85) (Canberra: Commonwealth of Australia, 2018), online: <alrc.gov.au/wp-content/uploads/2019/08/dp85_1_june_2018_.pdf $>$ [ALRC Report]).

$14 \quad$ ALRC Report, ibid at 21.

$15 \quad$ Campbells Cash \& Carry Pty Ltd v Fostif Pty Ltd, [2006] HCA 41. 
for maintenance and champerty (archaic legal doctrines that are described further below) were eliminated. ${ }^{16}$ Second, in the $1990 \mathrm{~s}$, contingency fee agreements were legalized. ${ }^{17} \mathrm{TPF}$ became more widespread in the UK after a series of access-to-justice reforms that further enabled the use of contingent arrangements, and also permitted ATE insurance. ${ }^{18}$

Following the development of the Australian and UK industries, commercial litigation funding has risen to prominence in the United States over the last decade. In the US, the regulation of litigation funding occurs at the state level. Some states remain "maintenance and champerty states" that do not allow litigation funding at all. ${ }^{19}$ Other states allow litigation funding, but have started to introduce legislation to regulate it in certain respects. ${ }^{20}$

Canada's industry has developed more recently still. The Canadian approach to litigation funding represents a hybrid between the Australian and US styles of litigation funding, which reflects important differences between the legal systems in all three countries. For instance, in Australia, due to the prohibition on contingency fees and the harsh adverse costs regime, it can be prohibitively costly or risky to pursue cases absent external funding. When cases are funded in Australia, funders typically pay the lawyers' full hourly fees and will pay any court-ordered cost awards. By contrast, in the US, contingency fees are prevalent in commercial litigation and adverse costs are very rare, and therefore the risk of paying courtordered costs does not need to be allocated. As a result, funders in the US often cover only a portion of the law firm's fees as a case progresses, and the law firm carries the remainder in return for a partial contingency fee. Canada is essentially a hybrid between these jurisdictions; contingency fees are permissible, although they are not common in commercial litigation. In most provinces, there is an adverse costs regime, but costs awards, which would typically fall in the range of 30 to 60 percent of actual costs, are not as high as in Australia. This dynamic means there is potentially greater opportunity for flexibility in litigation funding arrangements in Canada.

The institutional funding industry in Canada generally remains unregulated. ${ }^{21}$ Thus, the only constraints on the industry come from the law of the jurisdiction in which the dispute is proceeding, both substantive and, if applicable, procedural or regulatory (by way of regulation upon the lawyers themselves). ${ }^{22}$ That said, there are some jurisdictions where regulation is now coming into place and funder industry organizations, such as the Association of Litigation Funders, set out a Code of Conduct for members. ${ }^{23}$

Whillans, supra note 12 .

Ibid.

Ibid.

Michael F Aylward \& Mary Craig Calkins, "Beyond Champerty: The Rise of Third Party Litigation Funding" (Paper delivered at the American College of Coverage and Extracontractual Counsel 2017 University of Michigan Law School Symposium, Ann Arbor, Mich, 20 October 2017) at 3-7, online: <coverage.memberclicks.net/assets/LawSchoolSymposium-UMich/accec_symposium_2017 michigan fullattendeehandout-sm1.pdf $>$.

Whillans, supra note 12.

Victoria Shannon Sahani, "Judging Third-Party Funding” (2016) 63:2 UCLA L Rev 388 at 396-97.

For example, a law on maintenance and champerty may direct terms for an LFA or require disclosure of the existence of a funder's involvement in any given dispute. See Mick Smith, "Mechanics of ThirdParty Funding Agreements: A Funder's Perspective," in Lisa Bench Nieuwveld \& Victoria Shannon Sahani, eds, Third-Party Funding in International Arbitration (Alphen aan den Rijn, The Netherlands: Kluwer Law International, 2012) 19 at 20.

23 See e.g. Arbitration Ordinance (HK), Cap 609, online: <elegislation.gov.hk/hk/cap609>; Smith, ibid at 20 . 


\section{B. LITIGATION FUNDING VERSUS LITIGATION INSURANCE}

While the term "litigation funding" is often spoken of as a monolith, it potentially encompasses a number of very different products. ${ }^{24}$ This article focuses on true TPF, which is to say the payment of fees or disbursements in exchange for a return or share of the recovery. This is distinct from litigation insurance products, the most common of which are BTE insurance and ATE insurance. ${ }^{25}$

BTE insurance is purchased before an unforeseen legal event, and used to indemnify the costs of the litigation (such as fees, disbursements, and adverse costs), and in many different types of litigation. ${ }^{26}$ ATE insurance is used predominantly in the realm of personal injury cases. It can be purchased by lawyers acting on contingency fee cases to protect the insured against a costs award after a claim has arisen, and in the event the insured loses the case. ${ }^{27}$ An insurer will perform some level of due diligence on the case to assess its likelihood of success on the merits. The insurer then typically agrees to pay any adverse costs award against the insured (and in some cases may pay disbursements).

ATE insurance is less common than BTE insurance. It is often used in situations where law firms are willing to take on the risk of carrying fees on the file for a contingency return, but not the risk of an adverse costs award, or potentially disbursements. BTE and ATE insurance providers are typically required to be licenced as insurers, or at least partnered with licenced insurers for the purpose of offering insurance products. By contrast, TPF is not insurance, and funders are not typically licenced or regulated as insurers.

\section{REASONS FOR THIRD-PARTY FUNDING AND FUNDING STRUCTURES}

\section{A. Why Parties May Seek Third-Party Funding}

Historically, funding for disputes was typically pursued by cash-strapped litigants. Interest in institutional TPF began to increase around the time of the economic downturn of $2008 .^{28}$ Academic studies on the subject attribute this interest to four driving forces:

1. increasing access to justice: the use of TPF can "help individuals bring claims that they could not otherwise afford to bring",29

2. providing a means for smaller or insolvent companies "to pursue valid claims they could not otherwise afford... and that are usually too risky for a contingency fee attorney to accept"; 30

See von Goeler, supra note 3 at 52-56. Another common product for entities operating internationally is political risk insurance, which, again in exchange for a payment of a form of premium, functions as a form of BTE insurance to protect against damages incurred by actions of the host state (such as expropriation, war, or political unrest).

Another common form is political risk insurance: see ICCA-QMUL Report, supra note 4 at 209. ICCA-QMUL Report, ibid at 33-35.

Ibid.

Ibid at 18 .

Sahani, supra note 21 at 395.

Ibid. 
3. permitting larger companies to maintain their cash flow while pursuing a meritorious claim, as "funders can offer them a fixed payment system for managing their litigation costs"; 31 and

4. allowing investors to make investments that are independent of company valuations, financial markets, and stock prices, that is "a discrete investment [that] is independent from market conditions in terms of the value of the plaintiff's claim or defendant's liability.",32

The rising costs of litigation combined with increased pressure on legal budgets means controlling the costs of litigation is an issue of increasing concern for litigants of all types. The ability to share these risks with a third party may be attractive even to entities with strong businesses and cash flows. TPF provides not only the financial resources to pursue a claim, but also opportunities to manage financial risks associated with the pursuit of a claim through litigation. A plaintiff can transfer some or all of those risks to the funder. It can also avoid the negative accounting treatment of litigation, whose expenses, if paid monthly as in the normal course, would have the effect of reducing a company's profit and thus affecting corporate valuations. ${ }^{33}$ The plaintiff also then has the opportunity to achieve a successful recovery, without having to pay legal fees and other costs as the claim progresses and without having to obtain or allocate funds to deal with the costs consequences should the claim fail (depending on the arrangements agreed with the funder). Funding may also assist litigants to retain their first choice of counsel, who may not otherwise be able to act on the case if required to do so on contingency. The availability of funding further allows law firms to take on meritorious cases that they might not have otherwise been able to accept.

It is becoming increasingly common for parties to seek litigation funding not only to obtain capital to finance the lawsuit itself, but also to obtain working capital to maintain business operations while the dispute remains ongoing. ${ }^{34}$ Having a dispute financed by a third party may allow a company to pursue both a project and the dispute, whereas without it, they may have only been able to pursue one. This working capital, like fee and disbursement funding, is non-recourse and typically remains secured only by the litigation proceeds. The proceeds in such cases must therefore be sufficient to reimburse both the litigation funding and the working capital, while providing an appropriate return for all parties. Working capital requests typically arise in cases where the wrongdoing that is the subject of the lawsuit has deprived the claimant of its only or primary revenue stream, and the existence of its business would otherwise be jeopardized while the dispute is resolved. ${ }^{35}$

A common concern surrounding TPF is that it will lead to more frivolous claims being pursued. These concerns are likely misplaced, however. The doctrines of maintenance and champerty (discussed below) were created to protect against the improper advancement of potentially vexatious litigation claims for profit, and remain in force in many jurisdictions. Further, a commercially rational funder is looking to maximize its returns, and will subject

Ibid at 396.

Ibid.

ICCA-QMUL Report, supra note 4 at 20.

Ibid at 39.

Ibid at $20-21$. 
prospective cases to significant due diligence given the risks involved in investing in litigation. A commercially rational funder would have no incentive to fund frivolous cases. Those that do will likely not remain in business for long. ${ }^{36}$ Proponents of TPF contend that responsible TPF has an overall salutary effect on the administration of justice by increasing access to justice for meritorious cases, and by making it more likely that those cases are ultimately decided or resolved on the merits. ${ }^{37}$

\section{B. DifFERENT FUNDING STRUCTURES: EXAMPLES}

It is important to note at the outset of this discussion that there is no singular "industry standard" LFA or terms for a funding structure. ${ }^{38}$ Today, there are many variations in funding structures depending on the funder, the type of dispute, and the financial terms ultimately reached in any given LFA. The original approach to providing this institutional funding was for the funder to provide financing with respect to a single case, and in exchange it would receive a portion of the proceeds if the case was successful.

This type of funding model could work for a relatively new company that, still in a startup phase, might not have the financial means to fund a claim to enforce their rights and therein remain viable. Consider, for instance, the hypothetical example of a start-up innovator of a patented technology that increases oil and gas pipeline efficiency who enters into licencing discussions with pipeline owners and operators. The negotiations do not come to fruition, and the pipeline owners eventually deploy a technology that bears a strong resemblance to the technology patented by the innovator. The start-up notices that other operators have since started to adopt the technology as well. The start-up was relying on licencing its technology to the pipeline owner as its principal business and has little to no other revenue stream. Without the revenues it forecasted, the start-up is not in a position to fund day-to-day operations, let alone protracted litigation against multiple well-capitalized defendants to protect its intellectual property. Such a scenario may be suitable for TPF. Assuming that the potential damages for patent infringement are high enough, a funder could extend working capital to the start-up to allow it to continue its operations while also funding the litigation against the alleged infringers. Both the working capital and litigation funds would be non-recourse and secured only against litigation proceeds, freeing the company to raise funds in other ways by using its unencumbered property as collateral. This is also the model that commonly comes to mind in the so-called "David and Goliath" situation. In such situations, funding can level the imbalance between the parties. There could be a specific element or aspect to the dispute, or a unique attribute to a party, that creates an inequity, making the claim, while meritorious, less attractive financially.

This could also occur where a company has recently gone through an asset sale, and then faces a claim with respect to that business to which it needs to respond. As part of that response, the company uncovers a counterclaim that it considers meritorious and worth pursuing. However, as the counterclaim relates to the sold assets, the company does not necessarily want to spend a lot of time or resources on the counterclaim. The company could

\footnotetext{
$36 \quad$ Michael K Velchik \& Jeffery Y Zhang, "Islands of Litigation Finance” (2019) 24:1 Stan JL Bus \& Fin 1 at $32-33$. 
seek funding for its legal fees and expenses for the counterclaim, thereby incurring a benefit if the counterclaim is successful and not having to provision for further legal expenses or a possible loss if unsuccessful.

Situations in which a state expropriates a company's sole asset can also create a similar type of inequity that lends itself to TPF. This most commonly arises through investor-state arbitrations in which capital-intensive projects developed by energy or resource companies are expropriated through the laws or actions of a foreign government, and the only recourse is through expensive treaty arbitration requiring specialized counsel and expert witnesses.

Another common example that lends itself well to TPF is in the case of an entity with a meritorious claim to unpaid royalties. The entity must pursue this claim due to an unexpected business loss, but that loss makes pursuing the litigation an unwise use of resources in the short term.

In addition to the traditional single case approach, more recently, institutional funders have begun to:

(1) "finance portfolios of cases ... to distribute risk across multiple actions and thus allow the financier to offer better pricing"; 39

(2) finance business operations by using the underlying high-value claim as collateral;

(3) monetize awards by receiving "an immediate, discounted payment" on the basis of an as-yet uncollected judgment;

(4) "cover premiums on an insurance policy against the risk of an award not being enforced"; 41 and

(5) "serve as a financial tool for respondents" (who have historically not been users of $\mathrm{TPF}$ ), allowing them to "seek protection against worse-than-expected outcomes."

Take a company that has more than one ongoing dispute in which it is involved either as the plaintiff or the defendant, and perhaps also a few legal disputes involving non-monetary claims. This range or volume of disputes lends itself to a portfolio solution by a funder. These portfolios are individually tailored and permit cross-collateralization through the portfolio (thereby potentially permitting the mix of claims, defences, and non-monetary litigation matters). Portfolios allow the funder to "recover its costs and return from the

\footnotetext{
Bogart, supra note 3 at 319.

Ibid.

Ibid.

Ibid. See this example given by The Judge: "The client knew that achieving the award was only going to be half the challenge, with a likely enforcement campaign ahead. Offers of capital advances of over US\$100 million were received on the basis the client would receive US\$100 million now and then receive an earn out based on the ultimate recovery in the future" (Verity Jackson-Grant, "Not Just Legal Fees...," The Judge (16 October 2018), online: <thejudgeglobal.com/not-just-legal-fees $>$ ). See also this further example: "[I]n one sizeable commercial arbitration claim, what started as a funding request for legal fees and expenses of $\$ 20$ million by a corporate client, resulted in a discussion for a separate $\$ 200$ million capital loan at 50 basis points above LIBOR" (Jackson-Grant, ibid).
} 
revenue-generating claims within the portfolio. In some cases, the business might also secure an advance on working capital against the claim value of the portfolio, to deploy within the business or simply to declare as profit." ${ }^{\text {33 }}$ This could arise where a company has a number of outstanding disputes with respect to amounts owing for remediation for historic or more current operations. By obtaining funding, the company is offloading the ongoing cost and risk in the disputes. As reported by a broker of ATE insurance in late 2018, a $£ 6$ million working capital advance to a mining company that it arranged allowed the company to monetize the mining company's claim allowing "the company to continue its current operation while their ICSID arbitration claim was pursued." $" 4$

If a company is looking to sell all or a part of its business, an ongoing dispute (in particular, if larger in value) or several ongoing disputes might impact the assessment of the business for purchase, or even the ability to sell. Securing funding to address any requirements for posting security for costs, day-to-day fees in pursuing the litigation, and any potential adverse costs awards could lessen the impact of the dispute on the prospects for a sale. Further, a purchaser and vendor might want to examine carving out a legacy dispute from the transaction so that the dispute stays with the vendor. The vendor, who will be selling the business, might not relish the prospect of then having to take on financially costly and lengthy proceedings to resolve the claim. Similarly, assuming legacy litigation may not be palatable to the purchaser, securing funding for the dispute could make the vendor more willing to retain the dispute in order to achieve its goal of a successful sale.

Funding could also be attractive if a company is looking to expand its operations. It wants to spend its capital on new ventures, but needs to assert a claim with respect to an existing facility. The litigation is expected to be costly and time-consuming as a result of the claims, which span years of the operating life of the facility. The company could approach a funder for a more typical one-off funding of the claim, or they could look to a funder and use the expected proceeds from the dispute as security to unlock investment capital for the new project. Because the funder understands disputes, and has managers experienced in litigation, the rates and terms could be preferential and more easily negotiated than with other traditional methods of financing.

The concept of providing TPF to defendants is notable because the TPF market, which was originally established to finance plaintiffs, has evolved so as to also service defendants. Outside of situations where a defendant has a valuable counterclaim, however, providing TPF to defendants remains uncommon, as a funder typically takes its return from cash proceeds to litigation. This raises challenges in how to compensate a funder when the

43 Gayner, Glasgow \& Landis, supra note 7 at 248. See also Jack Ballantyne, "Clyde \& Co Teams Up with Australian Funder" Global Arbitration Review (28 March 2019) at 248, online: <globalarbitration review.com/article/1189396/clyde-co-teams-up-with-australian-funder>.

44 Jackson-Grant, supra note 42. The report added:

This budget was agreed against ongoing known expenses, which resulted in the itemisation of various overheads for the business, even down to a line item for the food and upkeep of the security dogs.

While many deals won't identify micro expenses to this extreme, this example does aptly demonstrate just how removed from the legal expenses such financing can become. Fundamentally, once you recognise the award as an asset, a whole range of potential capital options can present themselves (ibid). 
defence of a claim is successful. ${ }^{45}$ One option for a defendant or respondent looking to secure funding, without a counterclaim, would

contain an obligation of the funder to pay for the costs of defending against the claim, while the respondent promises to pay the funder a share of the amount by which its liability has been reduced, comparing the amount originally claimed with the amount awarded (or settled at). The return may be calculated as a percentage of the margin, a multiplier of the capital invested, or interest on the investment which increases over time. $^{46}$

Another avenue for funding defendants or respondents is in the portfolio funding model discussed above, which spreads risk across a number of matters, including some where the party is the plaintiff or claimant and others where the party is the defendant or respondent. ${ }^{47}$

There are two main ways in which a party to a dispute can approach funding: single case funding and portfolio funding. ${ }^{48}$

\section{Single Case Funding}

This occurs where a party has a single dispute for which they would like to seek funding. Such funding is typically "on a case by case basis for high value litigation claims, where the claimant lacks the resources or risk appetite to proceed without financial support."49 The funding is provided on a non-recourse basis, meaning if the matter is unsuccessful, the funded party does not owe the funder anything. Single case funding is usually only available to claimants or plaintiffs in a dispute. ${ }^{50}$

TPF of single cases can take on a number of different structures to suit the needs of each individual client, the funder, law firm, and case. Broadly speaking, however, TPF will reflect either a form of risk shifting or risk sharing. In a risk shifting model, the third-party funder will pay for 100 percent of the legal fees and disbursements necessary to bring the lawsuit. In exchange, the funder will receive a return from the proceeds of the litigation. The returns (which are described in greater detail below) can be expressed in a number of ways, including as a multiple on the amount committed or invested by the funder, or as a percentage of the proceeds recovered. In a risk sharing model, the third-party funder will pay

ICCA-QMUL Report, supra note 4 at 23.

von Goeler, supra note 3 at 49.

An interesting aspect of respondent funding has arisen in international arbitration. See ICCA-QMUL Report, supra note 4 at 90 ("[p]articularly in the investment arbitration context, there are a number of examples of third-party funding provided for non-pecuniary interests"). In one case, the ICCA Task Force reports on a company with a competing interest in the oil exploration rights claimed by the claimant, who provided funding to the respondent state: Quasar de Valores SICAV SA v Russia (2012), SCC Case No 24/2007 (Arbitration Institute of the Stockholm Chamber of Commerce), online: $<$ italaw.com/sites/default/files/case-documents/ita1075.pdf $>$. A global not-for-profit also reportedly provided funding in line with its anti-tobacco policy to lower-income countries in defence of claims they had to respond to because of the not- for-profit's stated policy objectives: see Phillip Morris Brands SARL v Uruguay (2016), ICSID Case No ARB/10/17 (International Centre for Settlement of Investment Disputes), online: <italaw.com/sites/default/files/case-documents/italaw7417.pdf>.

Additional types of funding solutions can be sought for other circumstances, such as enforcement funding.

Woodsford Litigation Funding, "Single Case Litigation Finance," online: < woodsfordlitigationfunding. com/us/litigation-finance/single-case-litigation-finance>.

Smith, supra note 22 at 28. 
for a portion of the legal fees, while the law firm carries the remaining portion in exchange for receiving the carried fees plus a reward or percentage out of the proceeds. The funder will still typically pay 100 percent of the disbursements in this model, although in some cases clients may also pay a portion of disbursements to ensure incentives remain aligned as the litigation progresses.

Risk sharing models may be preferred by clients as they tend to better align the interests of the lawyers, funder, and client in the underlying litigation than a risk shifting model. ${ }^{51}$ In addition, the risk sharing model allows law firms who otherwise do not take cases on contingency to take on a moderate partial contingency risk for a potential reward. For instance, a firm may enter an LFA with a funder and client that provides for 70 percent of the firm's fees being paid on an ongoing basis, with the remaining 30 percent fees received upon recovery of the proceeds, in addition to a success premium or percentage negotiated in advance.

The risk shifting models entertained by funders vary, and will depend on the litigation and the needs of the clients on a case-by-case basis. For instance, in the class proceedings context, class counsel typically take cases on full contingency. The firms who bring such cases thus tend to be specialized and structurally equipped to take on large, multi-year cases on full contingency. Contrast this with a situation where a funder and a law firm entered into a hybrid retainer whereby the funder agreed to pay 50 percent of the firm's fees while it carried the remaining 50 percent at risk, to be written off if the lawsuit was unsuccessful. That scenario was before the Ontario Superior Court of Justice, which commented that " $[t]$ he novelty of the hybrid retainer that combines a partial contingency fee with a fee-for-services retainer strikes me as a positive factor ... this approach which partially protects the financial and human capital of class counsel may expand the roster of firms prepared to assume the risks of class action litigation." 52

\section{PORTFOLIO FUNDING}

As the litigation funding market matures, portfolio funding is becoming increasingly common. Unlike single case funding, where the funder provides non-recourse financing directly to a claimant that is secured only by the proceeds from that case, in portfolio funding, a funder will extend funding to (most commonly) a law firm or a client directly that covers a number of different cases. As with single case funding, there are various types of portfolio funding models. In the law firm portfolio model, the funder has a contractual relationship with the firm only. ${ }^{53}$ The clients are not involved. The various cases in the portfolio are cross-collateralized, such that it is the overall performance of the portfolio that defines the return. The funder has recourse to the law firm only, and takes security from the law firm's contingency fee revenue stream, rather than from the end clients' settlement or award.

ICCA-QMUL Report, supra note 4 at 27-28.

Houle v St Jude Medical Inc, 2017 ONSC 5129 at para 79 [Houle], aff'd 2018 ONSC 6352.

Ballantyne, supra note 43. 
In the corporate portfolio model, funders generally invest in claims for the same client, funding that client directly rather than the law firm. Corporate portfolio funding allows companies to monetize pools of litigation to produce steady capital inflows over time as the disputes progress. Fee overruns in one case can be offset by other cases progressing more efficiently. The funds can also be used for unrelated capital and operating expenditures. This approach also potentially allows cases with lower damages potential to be funded, as the decreased risk profile presented by the portfolio of cases often means a funder can afford to take lower returns.

Portfolio funding is relatively new. While it has not been considered by a court or bar association in Canada, it has attracted criticism from the Professional Ethics Committee of the New York City Bar Association (NYCBA), which released a non-binding opinion concluding that portfolio financing runs afoul of New York State's rule preventing lawyers and law firms from sharing legal fees with non-lawyers, also known as "fee splitting." rule against fee splitting is meant to ensure the professional independence of lawyers. Most provinces have similar regulations forbidding fee splitting, which prohibit lawyers from dividing fees with non-lawyers. ${ }^{55}$

Commentary published in response to the NYCBA show that there is disagreement within the New York bar over whether portfolio funding actually offends rules prohibiting fee splitting. ${ }^{56}$ In particular, the NYCBA opines that traditional bank financing to a law firm is not caught by the rule against fee splitting, even though the financed firm's ability to repay its loan may in practice be dependent on it receiving contingent fee income from its cases. The only distinction between these two types of financing is that litigation funding is nonrecourse, and the impact of this distinction on fee splitting remains to be seen.

As discussed above, given the scrutiny applied by funders for disputes, and the experience usually brought by counsel at institutional funders, having funding in place could also have a soft impact in providing some assurance as to the value or merits of a dispute. Having a funder on board could also provide an additional assessment of those merits for potential purchasers of a business who may want independent counsel to review potential disputes but cannot obtain all of the information necessary to undertake this review or are facing time pressures related to the transaction.

\section{The Funding Agreement}

LFAs provide the terms under which a funder will be providing resources to the disputing party and what the disputing party will provide in return. These are by their very nature also confidential and unique to each situation and funder. There is no "industry standard" set of terms or form of agreement. Rather, institutional funders will each have a specific type of

54 The Association of the Bar of the City of New York Committee on Professional Ethics, "Formal Opinion 2018-5: Litigation Funders' Contingent Interest in Legal Fees" (30 July 2018), online: <s3.amazonaws. com/documents.nycbar.org/files/2018416-Litigation_Funding.pdf $>$.

55 See e.g. Law Society of Ontario, Rules of Professional Conduct, Toronto: LSO, 2014, ch 3.6; Law Society of Alberta, Code of Conduct, Edmonton: LSA, 2018, ch 3.6-7.

56 Anthony E Davis \& Anthony J Sebok, "New Ethics Opinion on Litigation Funding Gets It Wrong," New York Law Journal (31 August 2018), online: <law.com/newyorklawjournal/2018/08/31/new-ethicsopinion-on-litigation-funding-gets-it-wrong/>. 
case that they will fund, with some, for example, targeting portfolio or other types of models, along with their own notions on assessment, risk tolerance, and terms. Notwithstanding that each agreement will have distinct attributes, there are certain types of clauses that each LFA will generally contain.

\section{A. Returns}

The proceeds, or returns, structure of the LFA will be a critical provision as it outlines what will be due to the funder if the funded party is successful in the dispute. Typically, third-party funders seek a share of the ultimate amount recovered in a dispute in the range of 15 percent to 50 percent (with the median figure being around a third), depending on the costs and risks involved in funding the dispute. ${ }^{57}$ The funder's fee may also increase over time to reflect additional costs and risks being incurred.

Funding may be provided on the basis of a fee calculated as a multiple of the amount the funder invests. As the funder's investment and risk increases, so does the size of the funder's fee. Some funding agreements calculate the funder's fee by reference to the lesser (or greater) of a multiple of the funder's investment and a percentage of the successful outcome. As an example, in the Crystallex dispute against Venezuela, ${ }^{58}$ a funder is reported to have invested CDN\$76 million in the claimant mining company, who at the time of the claim was involved in insolvency proceedings under the Companies 'Creditors Arrangement Act ${ }^{59}$ The funding was primarily for the purpose of funding a claim against Venezuela for expropriating a gold mine. As a result of the successful decision for the mining company in that matter, the funder is now reportedly poised to obtain around $\$ 800$ million of the $\$ 1.4$ billion award. ${ }^{60}$

The amounts payable to a funder thus ultimately depend on the successful resolution of the claim. A successful outcome for these purposes may be a monetary award made in favour of the claimant or a settlement of the claim that involves a financial recovery by the claimant. If the claim fails, the funder receives nothing and, typically, remains liable for any fees due to the claimant's lawyer and other disbursements paid, together with any of the other party's costs that it has agreed to pay and that were incurred during the term of the LFA.

In the class proceedings context, courts in Ontario have been reluctant to pre-approve returns to third-party funders that are higher than the returns that the provincial Class Proceedings Fund would receive (generally 10 percent). Third parties who have funded class

See e.g. ICCA-QMUL Report, supra note 4 at $26-27$.

Crystallex International CorpvVenezuela, (2016), ICSID Case No ARB(AF)/11/2 (International Centre for Settlement of Investment Disputes), online: <italaw.com/sites/default/files/case-documents/italaw 7194.pdf' [ Crystallex 2016].

59 RSC 1985, c C-36 [CCAA].

60 Tom Hals, "Want to Sue Venezuela for Millions? These Firms Can Help, for a Price," Reuters (20 December 2018), online: <reuters.com/article/us-venezuela-lawsuits-finance-insight/want-to-suevenezuela-for-millions-these-firms-can-help-for-a-price-idUSKCN1OK0EP>. As discussed below, courts in domestic litigation will look to the reasonableness of the return to the funder in determining whether an LFA is enforceable. See Schenkv Valeant Pharmaceuticals International Inc, 2015 ONSC 3215 at paras 16-17 [Schenk], citing Contingency Fee Agreements, O Reg 195/04 (in a case where the reasonableness of LFA returns were challenged in the commercial litigation context, the Court held that up to a 50 percent return to a funder would be reasonable in certain circumstances. In arriving at this conclusion, the court analogized a funder's return to the statutory cap on lawyers' contingency fee recovery in Ontario of 50 percent). 
proceedings in Canada have generally funded only disbursements or provided an adverse costs indemnity, rather than also funding legal fees, and have proposed a return at or below the Class Proceedings Fund returns. However, in cases where a higher return has been proposed, or when there is no cap on a funder's return in the LFA, courts have generally declined to approve the LFA because the court is not in a position to assess the reasonableness of the funder's return relative to the overall return to the class members until the settlement approval motion. ${ }^{61}$ The Ontario Superior Court of Justice recently departed from this practice in $J B \& M$ Walker Ltd / 1523428 Ontario Inc. v. TDL Group.$^{62}$ In that case, the Court approved an LFA in a franchisee class action whereby the funder paid all fees and disbursements on a pay-as-you-go, non-recourse basis. Counsel would also receive a small top-up of 2 percent to 3 percent, to be determined at the end of the action. In exchange, the funder would receive between 22 percent and 26 percent of the litigation proceeds. ${ }^{63}$

In a commercial litigation context, however, the courts are not constrained by the same class protection policy concerns, and have signaled that returns in the 30 percent to 50 percent range may be commercially reasonable in the context of any challenge to an LFA based on allegations of champerty and maintenance (as will be discussed below, the court otherwise has no role in "approving" an LFA in commercial litigation cases).

\section{B. Priority OF RETURNS}

LFAs will usually set out the priority of payments following a recovery due to an award in the claimant's favour, including any interest and costs ordered, or on a settlement of the claim. Funding agreements often provide for payment of proceeds in the following order: (1) the funder is reimbursed for its investment or expenses to date, (2) the funder is paid its returns, (3) the lawyers (if applicable in a risk sharing model) are paid their remaining fees, (4) the lawyers (if applicable) are paid their returns, and (5) the balance is paid to the claimant. The funding agreement will also typically include a term that any recovery is to be paid into a trust account held by the claimant's lawyer, with the funder's portion held on trust for the funder and the balance on trust for the claimant. In some LFAs, the lawyer is a party to the agreement and agrees to distribute the proceeds in accordance with the priorities set out in the agreement. In other agreements, the lawyer is not a party, but is irrevocably directed by the claimant to make payments under the agreement at the funder's request.

\section{CONFLICTS OF INTEREST}

Because the funder will be obtaining an interest in the outcome of the dispute, and counsel will be working with that funder (and also may have an interest in the outcome of the dispute, depending on the risk sharing arrangement), there is the potential for counsel to have their interests divided between their client and the funder or themselves. At all times the obligations of lawyers working with funders is to act in the best interests of their clients,

$61 \quad$ Metzler Investment GMBH v Gildan Activewear Inc, 2009 CanLII 41540 (Ont Sup Ct J) [Metzler]; Houle, supra note 52.

2019 ONSC $999[T D L]$.

Ibid. TDL was the first decision in Canada in which a court was asked to approve a funding arrangement whereby the funder paid all of class counsel's fees, in addition to paying disbursements and providing an adverse costs indemnity 
abide by their duty of loyalty to their client, and act as instructed by their client (within the bounds of their other ethical duties).$^{64}$ A properly drafted LFA will expressly state that control over litigation decision-making and strategy rests solely with the client. There is, however, the possibility that a conflict could arise between the party to the dispute and the funder. One could imagine a scenario where there is a critical decision to be made, for instance whether to accept a settlement offer, and the two entities disagree. If a disagreement arises, the LFA should contain a procedure for how to resolve that dispute and be clear that the obligations of external counsel remain, at all times, with their client. External counsel should also prepare their clients for this possibility, and if appropriate recommend their client obtain independent legal advice before entering into any LFA.

\section{CONTRol, Termination, AND SetTlement}

In order to comply with remaining rules surrounding maintenance and champerty in jurisdictions where these doctrines still apply, third-party funders should not exercise control over strategy and day-to-day litigation decisions. Regardless of who is paying the legal fees, counsel have a duty to take instructions from the client and must always make independent recommendations that are in the best interests of their clients. In keeping with these restrictions, in certain circumstances courts may scrutinize LFAs and related evidence to assess whether the funding arrangement diminishes the plaintiff's right to instruct and control the litigation or impairs the lawyer's duties in any way.

In the commercial litigation context, courts have held that reasonable termination rights do not diminish the plaintiff's control over the litigation. To control its risk, an LFA will typically include a provision allowing the funder to terminate on notice. Sometimes that right to terminate is unfettered, and sometimes it requires as a condition precedent that new information emerge that causes the funder to no longer be satisfied about the merits or commercial viability of the litigation. As a balancing factor, the exercise of such termination rights may mean that a funder will no longer be entitled to all or a portion of its contractedfor return. In practice, such rights are seldom exercised as, once a funder expends significant capital to fund a case, the incentives of the funder and party are typically aligned to ensure that some return is achieved. For instance, in Schenk, the Ontario Superior Court of Justice examined a lawyer's letter of engagement and the funding agreement itself to conclude that the litigation funding arrangement (including rights to terminate where the funder reasonably ceases to be satisfied about the merits or commercial viability of the case) did not restrict the litigant's ability to instruct counsel. ${ }^{65}$

Courts considering LFA approval in class proceedings may take a different approach, given the policy mandate to protect the interests of class members. For instance, in Houle, the motions judge expressed concern that certain termination rights in the LFA might interfere with the plaintiffs' litigation autonomy, and held that the funder should not have the right to terminate the LFA in circumstances where the funder reasonably considered that the case is no longer meritorious or not commercially viable. The motions judge held that the 
funder should be able to terminate the LFA in other specific circumstances with court approval. $^{66}$

A funder will typically ask to be apprised of settlement negotiations and may offer nonbinding views on the same. Acceptance or rejection of a settlement offer should remain fully within the client's purview so that the funder does not exercise control over the conduct of the action. To guard against situations where a client may refuse a commercially reasonable settlement against the advice of their counsel, funders may insert a contractual safeguard. For instance, a funder may require that the parties engage in good faith negotiations on settlement offers, and in a situation where the funder, counsel, and plaintiff cannot agree, that the reasonableness of the settlement offer be referred to an independent arbitrator for binding determination.

\section{E. Privilege AND Confidentiality}

Matters of privilege and confidentiality arise in three general ways: (1) the necessary disclosure of information by a party when it is seeking funding, (2) continued disclosure of information during the dispute if that party obtains funding, and (3) the assertion of privilege or confidentiality over the terms of the funding arrangement and the LFA itself. In order to obtain funding, a party will need to disclose extensive information about a dispute and, once funded, such disclosure will continue for the duration of the dispute. This necessitates the disclosure of materials privileged to the litigation and solicitor-client privileged material. To date, no court in Canada has specifically addressed to what extent these communications are privileged; however, it is likely that litigation privilege, solicitor-client privilege, and common interest privilege could, alone or together, apply to these communications.

Litigation privilege attaches to all types of communication exchanged between a client, its counsel, and a third party when the communication is made for the dominant purpose of litigation. As the Supreme Court of Canada has explained, this is because the purpose of litigation privilege is to create a "zone of privacy" litigation and to ensure the efficacy of the adversarial process. ${ }^{68}$ Documents, discussions, and analyses related to the litigation that are shared with a funder - which are by definition shared for the dominant purpose of litigation — should therefore be captured by this privilege. Solicitor-client privilege protects communications between a lawyer and client and third parties where the communications are "essential to the maintenance or operation of the client-solicitor relationship." ${ }^{\prime 99}$ Documents, discussions, and analysis with a funder would directly support or enable the solicitor-client relationship, and may therefore be covered by this privilege as well.

At law, common interest privilege (also called deal privilege) is not a freestanding form of privilege. Rather, it is a well-established defence against a claim that privilege has been waived. Applied most commonly in the transactional context, common interest privilege protects communications between arm's-length parties to a prospective transaction so that 
they may share otherwise privileged legal opinions with one another in furtherance of their common interest in consummating a deal. ${ }^{70}$ As funders, clients, and lawyers are all sharing information between each other in furtherance of entering into a funding transaction, this sharing would likely fall within the "common interest" defence against waiver.

Parties to a dispute might have a confidentiality agreement that would need to be navigated before any disclosure could be made to a funder, and if entering a confidentiality agreement or order, a party to a dispute might want to consider how that order could align with potential disclosures to a funder if they might want to consider funding in the future. Confidentiality concerns could also arise for the counterparty to any dispute, who would not usually know about the approaches made to funders and specific disclosures, at least in the context of litigation.

The disclosure of information to a funder is also addressed by extension of the "implied undertaking" rule to funders. When producing documents or information to another party in litigation, the party receiving the documents is subject to an implied undertaking that it will not use them for any other purpose than the proceeding at hand. ${ }^{71}$ This rule has long been part of the common law in Canada, and has since been codified into some Canadian rules of civil procedure. $^{72}$ The implied undertaking rule has been extended to related third parties necessary for the litigation, "including experts, potential witnesses, consultants or others whose advice is relevant to the carriage of the litigation." ${ }^{, 73}$ The Federal Court of Canada has found that the implied undertaking rule expressly extends to a third-party litigation funder receiving information, stating that such disclosure by a plaintiff to the funder is "neither improper nor alien, collateral or ulterior to the litigation" "74 as long as the funder agrees to abide by the implied undertaking rule.

With respect to any privilege or confidentiality over the funding arrangement and LFA, some courts have found that litigation privilege attaches to the LFA itself, as "it was prepared and created for the sole purpose of the present litigation," and that disclosure of provisions of the LFA relating to details of the funding commitment would give the defendant "a tactical advantage in how the litigation would be prosecuted or settled, and the very essence of what the litigation privilege is designed to protect." ${ }^{75}$ Other decisions have taken a more selective approach and found that while the LFA as a whole is not subject to privilege, the individual terms concerning litigation strategy, budget, and other sensitive topics are privileged and should be redacted. ${ }^{76}$

Iggillis Holdings Inc v MNR, 2018 FCA 51.

Goodman v Rossi (1995), 24 OR (3d) 359 (CA).

See e.g. ON, Rules of Civil Procedure, RRO 1990, Reg 194, r 30.1.01(3); AB, Rules of Court, AR 124/2010, r 5.33 .

Seedlings Life Science Ventures, LLC v Pfizer Canada Inc, 2017 FC 826 at paras 32-33 [Seedlings II]. Ibid.

Seedlings Life Science Ventures, LLC v Pfizer Canada Inc (17 July 2017), Ottawa T-608-17 (Fed Ct). In this case, the plaintiff voluntarily disclosed a copy of the LFA with commercial terms redacted. The defendant moved for production of an unredacted version. Case Management Judge Tabib dismissed the defendant's motion.

Schneider v Royal Crown Gold Reserve Inc, 2016 SKQB 278 at para 10 [Schneider]; Hayes $v$ The City of Saint John, 2016 NBQB 125 [Hayes]; Stanway v Wyeth Canada Inc, 2013 BCSC 1585. 


\section{F. Disclosure of Funding Agreements}

The question of whether the existence of an LFA (or an LFA's terms) must be disclosed to the defendant(s) and the court is a developing issue, and will depend on the type of dispute and its forum. As is described in greater detail below, in the context of class proceedings and insolvency, third-party funding must be approved by the court supervising the proceeding. ${ }^{77}$ There is no such requirement in commercial litigation cases outside of these areas. However, in some cases a funded party may choose to disclose the existence of funding to the other parties. In contexts where the funded party must seek court approval, or where a funded party voluntarily discloses the existence of an LFA, the typical practice is to submit an unredacted version of the LFA to the court under seal, while delivering to the defendants either a copy of the specific terms at issue, or a copy of the LFA redacted to remove privileged and strategic terms that may include the amount of the investment, the percentage or apportionment of the return, or how settlement discussions are to be conducted. ${ }^{78}$

In the international arbitration context, as described in greater detail below, the practice is to promptly disclose the existence of a funding arrangement, and the identity of the funder, so that arbitrators can identify any potential conflicts, and increasingly so that the parties can explore any potential issues surrounding who is to pay for adverse costs awards.

\section{G. Adverse Costs ANd Security for CostS}

Most jurisdictions in Canada employ a "loser pays" costs regime for civil litigation, meaning that the party who is successful in the litigation is presumptively entitled to be indemnified by the unsuccessful party for some portion of the legal fees and disbursements it incurred. ${ }^{79}$ Adverse costs consequences can be a key consideration in whether and how to bring a civil claim, and can affect the dynamics between parties within litigation. As such, they also tend to be a key motivator for parties seeking third-party funding. The location and nature of the case will in many cases determine the nature of the funding sought, and what provision may be made for adverse costs in an LFA. Third-party funders may also agree to make a provision for security for costs orders in an LFA.

While parties in an LFA may agree that a funder will pay as cash any amount ordered as security for costs into court, a funder may also agree to satisfy any court-ordered security for costs by way of an undertaking to the defendants or a similar non-cash mechanism. While there are no decisions to date on point in Alberta, courts in Ontario have exercised their discretion to allow non-resident litigants with assets in foreign jurisdictions to provide undertakings as security for costs. ${ }^{80}$

Bayens v Kinross Gold Corporation, 2013 ONSC 4974 at para 41 [Kinross]; Arrangement relatif à 9354-9186 Québec inc (Bluberi Gaming Technologies Inc) v Ernst \& Young Inc, 2018 QCCS 1040 at para 85 [Re Bluberi].

78 Schenk, supra note 60 at para 29; Houle, supra note 52 at paras 26-27. expect to pay a portion of the successful party's costs. (Rules of Court, supra note 72 at Schedule C). Cosimo Borrelli, in his capacity as trustee of the SFC Litigation Trust v Allen Tak Yuen Chan, 2017 ONSC 1815; SolarBlue LLC v Aus, 2013 ONSC 7638 at para 22; Telesis Technologies, Inc v Sure Controls Systems Inc, 2010 ONSC 5288 at paras 61-67. 
In a recent decision approving an LFA in a class proceeding, the Ontario Superior Court of Justice cited this case law as authority for the sufficiency of a publicly traded and wellcapitalized third-party funder's undertaking in satisfaction of any security for costs order. ${ }^{81}$ In approving the undertaking, Justice Morgan noted that Bentham IMF, the third-party funder, was a substantial financial entity whose financial statements are a matter of public record as a publicly traded company. Moreover, the funder was backstopped by insurance, and attorned to the jurisdiction of the Ontario Superior Court to address any enforcement concerns. For the purposes of the motion, the defendants in Loblaw were provided a redacted copy of the LFA that withheld the commercial terms of the agreement, including the total adverse costs commitment. The defendants argued that they should have access to that figure. Justice Morgan disagreed, as an unredacted copy was provided to the Court, and Justice Morgan was satisfied upon reviewing it that the funder's obligations were sufficient to cover any likely costs award.

\section{H. RECOVERING COSTS OF FUNDING}

At present, the only reported case from Alberta dealing with recovery of fees for thirdparty funding is a personal injury decision in Dov. Sheffer.$^{82}$ In this case, the Court was asked to address costs following a lengthy trial that saw a damages award to the plaintiff. The plaintiff claimed in his bill of costs interest for a litigation loan; he asserted he was impecunious at the start of the action and required $\$ 30,000$ in funding to pay disbursements for trial. ${ }^{83}$ The defendant's objection was manifold: there was no precedent in Alberta for such disbursements, and there was no evidence on the appropriateness of the loan that was submitted; such interest would equate to double compensation as some interest was calculated on past loss of income; and the process and Rules of Court did not contemplate this type of disbursement. ${ }^{84}$ The Court agreed with these objections and did not allow recovery of the interest. ${ }^{85}$

Assessing whether the costs of funding can be recovered will involve a fact-specific review of the funding and claim for cost-recovery. As discussed below, a somewhat different practice might be developing in international arbitrations.

\section{LEgal FramewORK IN CANADA}

The legal considerations around TPF are shaped by the legal framework of the particular jurisdiction in terms of specific matters that relate to the provision of such funding and approaches to cost recovery for litigants. ${ }^{86}$ Because TPF is relatively new in Canada, the case law on matters specifically relating to institutional funding of disputes is sparse. There is, in particular, a dearth of reported case law in Alberta with respect to the legal considerations

David v Loblaw, 2018 ONSC 6469 at para 22 [Loblaw].

2010 ABQB 422 [Do].

Ibid at para 14 .

Ibid at para 15 .

Ibid at para 16. By contrast, see Bourgoin v Ouelette (2009), 343 NBR (2d) 58 (QB) where the Court permitted interest on a loan taken out for litigation purposes as a result of the plaintiff's limited means. See the White Paper released by Bentham IMF Canada which discusses the relationship between funding and cost-recovery systems: Bentham IMF, "Litigation Funding Roundtable: The Canadian Perspective" (September 2016), online:<benthamimf.ca/docs/default-source/default-document-library/white_paper. pdf $>$. 
around TPF, both in a more traditional sense and in modern institutional funding. This section discusses the growing body of jurisprudence around TPF that has developed in Canada. It will address how TPF aligns with the traditional prohibitions of maintenance and champerty and how TPF has been accepted in various types of litigation proceedings in Canada, specifically class action and commercial litigation.

\section{A. MaintenanCe AND Champerty}

The concept of a non-party to a dispute funding or providing financing to a party was once prohibited in Canada for violating the historic common law doctrines of maintenance and champerty. Maintenance prohibits an individual or entity from interfering with litigation in which they have no legitimate concern. ${ }^{87}$ It is "confined to cases where [an entity] improperly and for the purpose of stirring up litigation and strife, encourages others either to bring

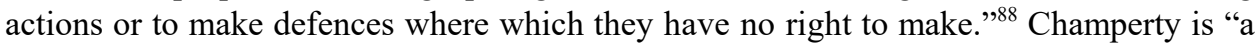
kind of maintenance in which the maintainor is entitled to a portion of the proceeds of the litigation as [their] reward for the maintenance." ${ }^{\prime 89}$ Both maintenance and champerty were imported from the UK into the common law of Canada as crimes. ${ }^{90}$ While the criminal aspect for maintenance and champerty was eliminated some time ago, they officially remain common law torts in Canada (other than Quebec)..$^{91}$

The prohibitions against maintenance and champerty reflected the long-standing belief that permitting third parties to a dispute to participate in litigation threatened the integrity of the justice system. ${ }^{92}$ These third parties were considered to be "stirring up strife" for improper motives. Over time, public policy and judicial attitudes have shifted to accept that, in certain circumstances, TPF can further the public interest and contribute to the integrity of the justice system. This shift primarily reflects an increased awareness within the legal community of the need to promote access to justice. ${ }^{94}$ TPF can allow financially disadvantaged individuals to bring claims that would otherwise be abandoned in light of the

$87 \quad$ Langtry v Dumoulin (1885), 7 OR 644 (Ch Div) at 661; see also Goodman v R, [1939] SCR 446; American Home Assurance Co v Brett Pontiac Buick GMC Ltd, 1992 NSCA 65 at para 10 [American Home Assurance], citing Findon v Parker (1843), 152 ER 976 at 978 (““'[m]aintenance’ is unjustified interference in a law suit by a stranger to the action who helps one of the parties, usually by paying or helping to pay the cost"); HG Beale et al, eds, Chitty on Contracts, 32nd ed (London: Sweet \& Maxwell, 2015) at para 16-059. Notably, "without maintenance there can be no champerty": see McIntyre Estate v Ontario (Attorney General) (2002), 61 OR (3d) 257 (CA) at para 26 [McIntyre Estate].

88 Stewart Estate v TAQA North Ltd, 2013 ABQB 691 at para 681 [Stewart Estate].

$89 \quad$ Ibid, citing Re Trepca Mines Ltd (No 2) (1962), [1963] Ch 199 (CA), cited in Pioneer Machinery (Rentals) Ltd v El-Jay, Inc (1978), 93 DLR (3d) 726 (Alta SC). See also American Home Assurance, supra note 87 at para 10 ("“champerty' is when the stranger shares financially in the successful outcome").

$90 \quad$ McIntyre Estate, supra note 87 at paras $18-19$.

91 Parliament abolished these crimes in 1953 when it undertook a consolidation of the Criminal Code, RSC 1985, c C-46. Within Ontario, An Act respecting Champerty, RSO 1897, c 327, statutorily prevents champertous conduct. See also Stewart Estate v TAQA North Ltd, 2015 ABCA 357 at para 470.

92 See Margetts (Next Friend of) v Timmer Estate, 1999 ABCA 268 at para 8, stating "the underlying concerns which motivate the rule are matters of public policy that attempt to safeguard the integrity of the trial process by minimizing the prospect of champerty and maintenance and abuse of process."

McIntyre Estate, supra note 87 at para 34.
94 Weigand v Huberman (1979), 108 DLR (3d) 450 (BC Sup Ct) at 451; Buday v Locator of Missing Heirs Inc (1993), 16 OR (3d) 257 at 267 (CA), which notes that where there was a valid claim, a bona fide commercial business arrangement to assist in that claim did not unnecessarily "stir up" the litigation, and thereby was not champertous. 
high costs of litigation, the length of time required to receive judgment, and the potential risk of having to pay damages. ${ }^{95}$

The case that started this line of inquiry with respect to TPF in Canada was McIntyre Estate, where the Ontario Court of Appeal examined whether lawyers were prohibited from entering contingency fee agreements with their clients for civil litigation because of the Champerty Act. ${ }^{96}$ Recognizing the benefits to contingency fee arrangements, the Court departed from the now antiquated view that all types of financial support to a litigant were prima facie violations of maintenance and champerty. Where a non-party is concerned about a litigant's rights, or has a genuine interest in the outcome of a dispute, the non-party's involvement (for example through contingency agreements) is not maintenance and not in violation of the Champerty Act. $^{97}$

Indeed, funding arrangements could permit an otherwise impecunious plaintiff to pursue justice, and provide assurances for a defendant that their costs could be recovered if successful. It remained, however, within the court's jurisdiction to examine the specific terms of the funding arrangement and determine whether the funding could be permitted..$^{98}$ In cases following McIntyre Estate, the Ontario courts found agreements that saw the funder recover not more than 50 percent of the proceeds could be permissible, but those providing for more, with open-ended exposure to the litigant, failed to truly provide access to justice. These agreements were champertous. ${ }^{99}$

McIntyre Estate has been cited with approval by Alberta courts for the principle that maintenance and champerty, as a matter of public policy, are important to protect "the administration of justice from abuse." ${ }^{100}$ Alberta courts have also addressed maintenance and champerty in the energy sector and found that where there is a genuine commercial relationship, the provision of funding will not be champertous. ${ }^{101}$ While a genuine commercial interest and bona fide business arrangement are acceptable reasons for providing assistance to a litigant, the exact type of funding arrangement will likely still be critical to a court's analysis and subject to scrutiny. A complete assignment of a right of action in full where there is an element of "officious intermeddling," no pre-existing commercial relationship, and "stirring up of strife" may indicate maintenance and champerty. ${ }^{102}$ This type of assignment is unlikely to be an issue where an institutional funder is concerned.

Ranjan K Agarwal \& Doug Fenton, "Beyond Access to Justice: Litigation Funding Agreements Outside the Class Actions Context" (2017) 59:1 Can Bus LJ 65; Dugal v Manulife Financial Corp, 2011 ONSC 1785 at paras 27-28, 33 [Dugal]; The Trustees of the Labourers' Pension Fund of Central and Eastern Canada v Sino-Forest Corporation, 2012 ONSC 2937 at para 15.

96

McIntyre Estate, supra note 87 at para 1; An Act respecting Champerty, supra note 91.

McIntyre Estate, ibid at para 28, citing Monteith v Calladine (1964), 47 DLR (2d) 332 at 342 (BCCA). Metzler, supra note 61 at para 67.

Schenk, supra note 60 at para 17; Metzler, ibid at para 67. The province of Quebec is not a common law jurisdiction and, accordingly, did not inherit historic UK common law on maintenance and champerty. Rather, the civil law doctrine of pactum de quota litis applies where a non-party to a dispute offers to provide funding to a party to the dispute in exchange for a portion of the proceeds. Quebec courts have confirmed that outside of certain non-commercial situations, contingency agreements are permissible under the law (see Montgrain c Banque Nationale du Canada, 2006 QCCA 557; Terreault c Bigras, 2005 QCCA 1243).

Silverado Oilfield Ventures Ltd v Davidson, 2014 ABQB 218 at para 25, rev'd 1773907 Alberta Ltd v Davidson, 2015 ABCA 150 [Davidson].

See Stewart Estate, supra note 88. See also Davidson, ibid at paras 33-42.

Davidson, ibid at para 26. 


\section{B. Class ACtion Litigation}

Once contingency fees were approved, it used to be common for class counsel to act on a contingent fee basis and to pay all disbursements. Class counsel would profit and recover their expenses if the litigation was successful; however, if the litigation was unsuccessful, class counsel would have to write off all disbursements and potentially pay a costs award. Through these types of fee arrangements, class counsel effectively funded the class action litigation. ${ }^{103}$ Unsurprisingly, few law firms were prepared to assume this risk, arguably resulting in the hindrance of access to justice for those with meritorious class action claims. ${ }^{104}$ In order to minimize the risks associated with class action litigation on contingency, parties began to enter into LFAs as a mechanism to shift some of the risk away from counsel. In this way, LFAs improved the economic viability of class action litigation and encouraged more law firms to take on these types of actions. ${ }^{105}$ Canadian courts have considered LFAs in the context of class action litigation over the last decade, and class action litigation was one of the first areas in Canada to see TPF arrangements with professional funding entities. Funding arrangements in these initial cases were quite traditional, reflective of the contingent basis formerly brokered with counsel; the funders agreed to indemnify the party they funded (the plaintiffs) against an adverse costs award, the funders provided (some or full) disbursement funding, and the funders would receive a relatively modest portion of the amount recovered. ${ }^{106}$

The current practice in class action litigation in Ontario where a funder is involved is for a representative plaintiff to enter into an LFA with the third-party funder and then seek court approval of the LFA prior to class certification proceedings. ${ }^{107}$ The purpose of the court approval is to ensure that the LFA is binding on all members of any class ultimately certified by the court and not just the representative plaintiff as the signatory to the LFA. The "court hearing the approval motion is charged with the responsibility of protecting the interests of the absent (future) class members." ${ }^{108}$ Presumably, an entity prepared to fund class proceeding in Alberta would also want court approval to ensure the agreement could be enforced. ${ }^{109}$

Charles M Wright \& Anthony O'Brien, "Third-Party Funding for Class Actions, and Control over the Litigation" (2014) 55:1 Can Bus LJ 165; see also Fantl v Transamerica Life Canada, 2008 CanLII 17034 (Ont Sup Ct J) at para 52, aff'd 2009 ONCA 377. Wright \& O'Brien, ibid at 167.

Ibid.

See Dugal, supra note 95.

Wright \& O'Brien, supra note 103, n 5: "In Fehr v. Sun Life Assurance Co. of Canada, [2012 ONSC $2715]$ at para. 89, Perell J. took the view that, in order to protect the administration of justice, a thirdparty funding agreement must be promptly disclosed to the court and the agreement cannot come into force without court approval."

108 Wright \& O'Brien, ibid at 167-68.

109 Class Proceedings Act, SA 2003, c C-16.5, ss 38-39. There is, however, no reported judicial consideration on this point as Alberta permits ex parte approvals for fee approval hearings in class proceedings (see Roth v Alberta (Minister of Human Resources and Employment), $2005 \mathrm{ABQB} 505$; the judicial considerations could be different). 
In Hobsbawn v. ATCO Gas and Pipelines Ltd., ${ }^{110}$ an LFA was purportedly approved for the plaintiffs in the class action. ${ }^{111}$ The Saskatchewan Court of Queen's Bench refers to this in Schneider v. Royal Crown Gold Reserve Inc. when determining "an application without notice requesting the approval of a litigation financing and indemnity agreement [LFA]."112 In Schneider, the plaintiff had initiated a class action with respect to investor purchases of units in mining cells of a property in British Columbia offered for sale by the defendant. After initiating the class action, Saskatchewan became a "costs jurisdiction," meaning that a representative plaintiff could be responsible for paying the defendants' costs and disbursements if the class action was dismissed. ${ }^{113}$ While no further comment is made on Hobsbawn in Schneider, the Court summarized its view on the test for an LFA to obtain court approval as follows:

a) the LFA is necessary to provide access to justice for the class members;

b) the division of any settlement or judgment as between the class members and the funder is appropriate;

c) the representative plaintiff will instruct counsel and counsel's duties are to the plaintiffs and not the third party funder;

d) the plaintiffs will conduct the proceeding in a manner that avoids unnecessary costs and delays;

e) the representative plaintiff will not become indifferent to giving instructions to class counsel in the best interests of the class members if he is insulated from an adverse costs award;

f) the LFA contains appropriate restrictions with respect to the sharing of information with the third party funder;

g) the third party funder is bound by the deemed undertaking and is also bound to keep confidential any confidential or privileged information; and

h) the LFA is governed by the laws of Canada and the province where the action is commenced and is subject to the exclusive jurisdiction of the courts of the province where the action is commenced. ${ }^{114}$

Various iterations of this test have continued to be present in more recent Ontario class action cases seeking approval of TPF. ${ }^{115}$

(14 May 2009), Calgary 0101-04999 (Alta QB) [Hobsbawn].

See Re ATCO Gas, 2013 CarswellAlta 644 (AUC) at para 56:

On February 28,2001, Don Hobsbawn, on his own behalf and of all other members of a class

having claims against ATCO Gas (the plaintiff), filed a statement of claim in the Alberta Court of Queen's Bench. The statement of claim sought re-payment of all [late payment penalties] made since 1982, or, in the alternative, a declaration of the court that all late payment penalties paid since 1982 should be reassessed at five per cent annual interest and restitution of any over-payments made to the class members."

The matter ultimately was certified as a class action for purposes of a negotiated settlement on 20 July 2009 (ibid at para 57).

$112 \quad$ Supra note 76 at para 1.

$113 \quad$ Ibid at paras 4-5.

$114 \quad$ Ibid at para 8, citing Hayes, supra note 76 at para 4.

115 Houle, supra note 52; Loblaw, supra note 81; TDL, supra note 62. 


\section{COMMERCIAL Litigation}

The courts have extended the principles developed with respect to TPF in the class action context to private commercial litigation. In Schenk, Justice McEwen of the Ontario Superior Court of Justice considered whether the rules against maintenance and champerty prohibited a plaintiff of limited means from entering into an LFA with a UK funder. ${ }^{116}$ Pursuant to the LFA, the UK funder agreed to pay for all legal fees and disbursements in exchange for a portion of the amount recovered. The agreement was conditional upon court approval, which approval the defendant opposed. The Court considered its jurisdiction with respect to the LFA to be ensuring "the statutory and common law prohibition on champerty and maintenance" 117 in Ontario were not violated. While the Court concluded the LFA was not champertous per se, and found no reason "why such funding would be inappropriate in the field of commercial litigation," 118 the Court did take issue with two specific provisions of the LFA. First, the terms of the agreement were open-ended, resulting in an inability to determine what the ultimate payout to the funder would be. ${ }^{119}$ It was likely that the funder would receive more than 50 percent of the proceeds. If the LFA were a contingency fee arrangement, it would be disallowed by the applicable regulations, and there was no authority before the Court indicating such percentages could be approved in funding arrangements. ${ }^{120}$ Ultimately, Justice McEwen refused to approve the LFA, but allowed the plaintiff and the third-party funder to revise the agreement to address these issues. The Court subsequently approved the amended agreement in an unreported endorsement.

Since Schenk, one other Canadian court has considered an institutional funding arrangement in the context of private commercial litigation. In Seedlings II, the Federal Court considered an LFA where a third-party funder agreed to pay a portion of the plaintiff's legal fees and disbursements on a non-recourse basis, as well as any court-ordered costs. ${ }^{121}$ As was the practice for class action litigation and in Schenk, the plaintiff and the third-party funder brought a motion, on notice to the defendant, for court approval of their LFA. Such was not required by any statute or precedent from the Federal Court, resulting in the Court's decision declining jurisdiction to grant such a remedy or make such a determination. ${ }^{122}$ The Court reasoned that, unlike in class action litigation where courts must help protect vulnerable class

Schenk, supra note 60 at para 11. As reported in this decision "[c]ounsel could not locate any cases in which third party funding has been extended to the context of commercial litigation" (ibid at para 8). Ibid at para 8 .

Ibid at para 8

Ibid at paras $12-19$.

Contingency Fee Agreements, supra note 60; Schenk, supra note 60 at paras 16-18.

Seedlings II, supra note 73 . In this case, the plaintiff, a small research and development company, initiated a claim for patent infringement by the defendant (ibid at para 1). As set out in ibid at para 6:

The moving parties' notice of motion and written representations seem to draw their inspiration from the Ontario Superior Court of Justice's practice and procedure in approving funding agreements in the context of class proceedings, as very recently adapted in one instance in the context of private commercial litigation [Schenk]. Because the Ontario Superior Court is a court of general original jurisdiction, its jurisdiction to enquire into and approve the terms of funding agreements incidental to proceedings before it has not been questioned. However, the Federal Court's jurisdiction is statutory and cannot be presumed. The Federal Court has jurisdiction to consider and apply provincial laws where they are ancillary to the disposition of the substantive issues that are properly before it. It also has plenary jurisdiction to control its own process. But it does not have jurisdiction to grant remedies and make final determinations of rights in disputes and matters over which it has not been expressly granted jurisdiction by statute and in accordance with the requirements set out in ITO - International Terminal Operators Ltd v Miida Electronics Inc., [1986] 1 SCR 752. 
members (or abide by certain statutory requirements), ${ }^{123}$ including class litigation over which the Federal Court had statutory authority, ${ }^{124}$ no such policy considerations exist in the context of the within litigation:

The manner in which [the plaintiff] chooses to fund a litigation it has every right to bring is of no concern to the Court or to the Defendant.

The Defendant has no legitimate interest in enquiring into the reasonability, legality or validity of Seedlings' financial arrangements ... because they do not affect or determine the validity of the rights asserted by Seedlings in this action. ${ }^{125}$

\section{INSOLVENCY LiTIGATION}

Insolvency litigation, similar to class action litigation, requires funding agreements to receive the approval of the court. ${ }^{126}$ The first matter in Canada to consider such, $R e$ Crystallex International Corporation, involved a Canadian company that had rights to develop a gold mine in Venezuela. ${ }^{127}$ In December 2004, Crystallex International Corporation (Crystallex) raised "\$100 million to be used in the development of [the project] by selling units consisting of a senior unsecured $\$ 1,000$ note [the "Notes"] and 65 common shares." 28 The Notes were set to mature on 23 December 2011. "At the time of the issuance of the Notes, the required mining permits had not yet been obtained" but Crystallex "expected to receive the permit and approvals" during the first quarter of 2005. "129 "That did not occur."130 Rather, on 3 February 2011, the state-owned Venezuelan corporation counterparty to the Mining Operation Contract (MOC) with Crystallex purported to "unilaterally rescind" the MOC. As a result, on 16 February 2011, Crystallex filed a Request for Arbitration with the International Centre for Settlement of Investment Disputes against Venezuela ${ }^{131}$ for restitution of the MOC, issuance of the requisite permits, and compensation for interim losses or, in the alternative, $\$ 3.8$ billion for the value of its investment. ${ }^{132}$

Class Proceedings Act, 1992, SO 1992, c 6; Class Proceedings Act, supra note 109.

Federal Court Rules, SOR/98-106, Part 5.1.

Seedlings II, supra note 73 at paras 22-23 [citations omitted]. The Alberta Court of Queen's Bench, in Jacobi v Newell No 4 (County) (1992), 136 AR 165, when asked to determine whether the action was an abuse of process because the plaintiffs' claim was funded by an organization to which one of the defendants was a member (and contributed funds), held: "where the financing comes from for the purpose of pursuing a lawsuit is of no concern to the court and does not create an abuse of process ... a court should not be concerned with how an action is funded. That is not for the courts to know and in my judgment cannot be considered an abuse of process" (at para 19). Whether such funding violated maintenance and champerty was not before the Court.

Guillaume Michaud, "New Frontier: The Emergence of Litigation Funding in the Canadian Insolvency Landscape" in Janis Sarra et al, eds, Annual Review of Insolvency Law 2018 (Toronto: Thomson Reuters, 2019) 221 at 257 . In addition, "besides any requirement with respect to financing charges under the $C C A A$ or $B I A \ldots$ it could be argued that litigation funding agreements are non-ordinary course agreements, which should be brought to the attention of the court in an insolvency matter" (ibid at 237). 2011 ONSC 7701 at para 5 [Re Crystallex 2011].

Computershare Trust Company of Canada v Crystallex International Corp, 2009 CanLII 71007 at para 2 (Ont Sup Ct J) [Crystallex 2009].

Ibid at para 3 .

Ibid.

Ibid at para 8. See Crystallex 2016, supra note 58.

Crystallex 2009, ibid at para 9. 
The difficulty immediately encountered by Crystallex was, as a result of the purported cancellation of the MOC, it did not have the funds to pay out the Notes on 23 December 2011. As a result, both Crystallex and the holders of the Notes (the Noteholders) filed separate and competing applications under the $C C A A \cdot{ }^{133}$ Approximately one month later, on 20 January 2012, the Ontario Superior Court of Justice approved an interim bridge loan in the amount of $\$ 3.125$ million from Tenor Special Situations Fund LP (Tenor Fund) to Crystallex pending a longer term DIP financing agreement. ${ }^{134}$ The eventual DIP provided various financial terms including, but not limited to: (1) the advance of \$36 million to Crystallex due and payable on 31 December 2016, and (2) the receipt by Tenor Fund of additional compensation equal to 35 percent of the net proceeds of any arbitral award or settlement. ${ }^{135}$ This was opposed by the Noteholders, but approved by the Court upon being satisfied that the board acted on an informed basis in arranging for the funding and in good faith with a view to the best interests of Crystallex and its stakeholders. ${ }^{136}$ The Ontario Court of Appeal upheld this decision because the $C C A A$ "permits a supervising judge to approve financing that may continue for a significant period after CCAA protection ends, without the approval of creditors." 137 The goal at all times is to eventually get a plan that will result in the viability and continuation of the company. The lower court's discretion in approving the DIP agreement, while it did constrain "the negotiating position of the creditors" was "reasonable and appropriate," and the Court was in the best position to balance the interests involved. $^{138}$

Interestingly, notwithstanding the presence of TPF from Tenor Fund, neither of the decisions by the Ontario courts referred to maintenance and champerty, or the law that had developed in Ontario with respect to institutional funding. ${ }^{139}$ The law on exactly what criteria to apply in situations where there is funding in an insolvency is currently outstanding. ${ }^{140}$

\section{Funding in Arbitral Proceedings}

Arbitration, whether domestic or international, generally involves similar considerations as discussed above in the litigation context. Certain key differences do, however, arise as a result of the specific laws, rules, or guidelines that may govern any one arbitration, and with respect to the increased potential for conflicts of interest with the addition of a funder as an entity with an interest in the dispute and the jurisdiction of the tribunal.

CCAA, supra note 59; Crystallex (Re), 2012 ONCA 404 at para 1 [Re Crystallex 2012].

Re Crystallex 2012, ibid at paras 2, 8, 15.

Ibid at para 28.

Ibid at para 36.

Ibid at para 64.

Ibid at para 82 .

Michaud, supra note 126 at 237.

Notably, at the time of writing, leave has been granted for an appeal to the Supreme Court of Canada in Re Bluberi, supra note 77 (SCC Docket No. 38594). In this case, the debtor, Bluberi, entered CCAA protection. Bluberi then entered into an LFA with a third-party funder to allow it to advance a $\$ 200$ million claim against its former lender through the $C C A A$ restructuring process, alleging that the lender had caused Bluberi's insolvency. The court-appointed monitor supported the funding arrangement and Bluberi moved for the Court's approval of the LFA. The lender brought a cross-motion for permission to call a creditors' meeting to approve its own plan of arrangement, through which the lender would be released from any liability to Bluberi. The Court approved the LFA, but this was overturned on appeal by the Quebec Court of Appeal in a decision that has since been stayed as "the issues raised before the Supreme Court of Canada are serious and novel": Arrangement relatifà 9354-9186 Québec inc (Bluberi Gaming Technologies Inc), 2019 QCCA 766 at para 8. 
While case law on funding of commercial litigation and domestic arbitration in Canada is lacking, there are a number of public international arbitration decisions that indicate the type of issues that might arise with respect to funding in an international arbitration. These offer some guidance on the issues that might arise in domestic arbitration. Given the advancement of tribunal determinations with respect to TPF in international arbitration, we will discuss that first, followed by funding for domestic arbitration.

\section{A. International Arbitration}

International arbitration is an area uniquely situated to attract TPF. Costs to pursue cases can be high. In particular, costs for investor state arbitration have risen dramatically in recent years ${ }^{141}$ and any ultimate collection of an award can be time-consuming and may involve enforcement in multiple jurisdictions. Companies may also be in a situation where the dispute, if pursued, involves their only asset, leaving them with few cash-flow options. For investor-state cases, in particular those involving a form of expropriation by the host state, this can be particularly acute. ${ }^{142}$ Given its prevalence, most sophisticated funders are now experienced in international arbitration, have in-house investment managers or legal counsel skilled in international arbitration from years in private practice, and are attracted to what can be very high damages claims and awards. A recent article by one international funder suggests that "[a]necdotally, our experience speaking with claimants, practitioners and others who are frequently involved in international arbitration suggests that most claimants involved in larger international arbitrations are either being funded or have, at some stage of the process, considered using funding." ${ }^{, 143}$ As noted in 2014 by one investor-state tribunal, TPF "is by now so well established both within many national jurisdictions and within international investment arbitration that it offers no grounds in itself for objection."144 Notwithstanding the increasingly commonplace nature of funding in reported investor-state disputes, there are issues around confidentiality and disclosure that are impacted by the applicable laws, rules, and guidelines governing a dispute.

Unlike court proceedings, there are heightened risks around potential conflicts of interest in arbitration. The tribunal ${ }^{145}$ is to remain independent and impartial to ensure the legitimacy of the process and the enforceability of an award. ${ }^{146}$ In practice, the funder will conduct their own due diligence and investigations into the identities of the parties and counsel in the dispute while considering the matter, and if for some reason both sides in a dispute ended up with funding, there is unlikely to be a conflict of interest as between the two funders. ${ }^{147}$ There

ICCA-QMUL Report, supra note 4 at 18.

See, for example, the situation in Re Crystallex 2011, supra note 127, where as a result of Venezuela's refusal to permit Crystallex to develop its gold mine, both the company and the holders of issued Notes filed applications under the CCAA, supra note 59.

Zachary Krug, Charlie Morris \& Helena Eatock, "International Arbitration" in Steven Friel \& Jonathan Banks, eds, Litigation Funding (London: Woodsford Litigation Funding, 2018), online: < gettingthe dealthrough.com/area/94/article/29334/litigation-funding-international-arbitration>. Alemanniv Argentina (2014), ICSID Case No ARB/07/8 at para 278 (International Centre for Settlement of Investment Disputes), online: <italaw.com/sites/default/files/case-documents/italaw4061.pdf > . Usually one or three individuals.

See e.g. Article 12(1) of Schedule 2 of the Alberta International Commercial Arbitration Act, RSA 2000 , c I-5 [ICAA], which notes the grounds for challenging an arbitrator if circumstances exist "that give rise to justifiable doubts as to [their] impartiality or independence" and Article 34 of Schedule 2 on recourse against an award.

Funders' own conflicts checks would prohibit this. 
is a unique and vexing issue around disclosure of the existence of funding to the tribunal and the potential for conflicts of interest with an arbitrator. A party to an arbitration might seek funding in the early stages of the case, before a tribunal is appointed, or later once a tribunal is in place. If a tribunal is already in place, the funder will also likely include in their initial due diligence the member(s) of the tribunal. If a tribunal is appointed after funding is secured, the funder would likely be included in that party's due diligence into potential arbitrator appointments; however, there is no control over who the opposing party or appointing authority may appoint to the tribunal. ${ }^{148}$ Moreover, each of these scenarios leaves the tribunal not knowing that there is another "interested party" in the dispute.

A party with TPF will need to carefully examine whether it is obligated to disclose the existence of that funding, and if there is no such obligation, then whether it should nonetheless make such disclosure. For example, an arbitration subject to the International Bar Association's Guidelines on Conflicts of Interest in International Arbitration would be impacted by General Standard 7(a), under which a party is obligated to inform the tribunal at the earliest opportunity "of any relationship, direct or indirect, between the arbitrator and ... any person or entity with a direct economic interest in, or a duty to indemnify a party for, the award to be rendered in the arbitration." 149 This could have the impact of obligating disclosure of the existence and identity of a funder. ${ }^{150}$ Disclosure of the existence of funding and a funder's identity may also be required by the rules applicable to the dispute. ${ }^{151}$ As a

This would be in situations where a three-member tribunal is constituted by each party appointing one member and those two members appointing the chair or third member, or in the event that any one party is unable to make an appointment, or the two appointed members are unable to agree, and the appointing authority needs to designate such tribunal member(s). Article 11(4) of Schedule 2 of the ICAA, supra note 146, designates the Alberta Court of Queen's Bench as the appointing authority. See also London Court of International Arbitration, "LCIA Arbitration Rules" (London: LCIA, 2014) arts 5-7, online: $<$ lcia.org/Dispute_Resolution_Services/lcia-arbitration-rules-2014.aspx $>$ (regarding the formation of a tribunal under the rules).

International Bar Association, "Guidelines on Conflicts of Interest in International Arbitration (2014)" (London: IBA, 2014) at 15, online: <ibanet.org/publications/publications_iba_guides_and_free_ materials.aspx $>$ [IBA Guidelines 2014].

150 Potentially, there are funding arrangements that are not captured by this definition. For a discussion on these, see ICCA-QMUL Report, supra note 4 at 89, n 180. Note also that General Standard 6(b) of the IBA Guidlines 2014, ibid at 13, which considers "any legal or physical person having a controlling influence on the legal entity, or a direct economic interest in, or a duty to indemnify a party for, the award to be rendered in the arbitration" as deemed to have the identity of the party to the dispute. Commentary on this notes that "[t]hird-party funders and insurers in relation to the dispute may have a direct economic interest in the award, and as such may be considered to be the equivalent of the party," and thus might require disclosure to the tribunal (ibid at 14).

151 For example, the Investment Arbitration Rules of the Singapore International Arbitration Centre at rule 24(1) provide that unless prohibited by a mandatory rule of law applicable to the dispute, the tribunal has the power to "order the disclosure of the existence of a Party's third-party funding arrangement and/or the identity of the third-party funder and, where appropriate, details of the third-party funder's interest in the outcome of the proceedings, and/or whether or not the third-party funder has committed to undertake adverse costs liability": Singapore International Arbitration Centre, "Investment Arbitration Rules of the Singapore International Arbitration Centre" (Singapore: SIAC, 2017) at 24(1), online: $<$ siac.org.sg/images/stories/articles/rules/IA/SIAC\%20Investment\%20Rules\%202017.pdf>. See also the not-yet-in-force provision from article 8.26(1) of the Comprehensive Economic and Trade Agreement between Canada and the European Union which states "[w]here there is third party funding, the disputing party benefiting from it shall disclose to the other disputing party and to the Tribunal the name and address of the third party funder" and such is to occur when the claim is submitted or without delay once the LFA is concluded: Global Affairs Canada, "Text of the Comprehensive Economic and Trade Agreement" (Ottawa: Global Affairs Canada, 2018), online: <international.gc.ca/trade-commerce/ trade-agreements-accords-commerciaux/agr-acc/ceta-aecg/text-texte/toc-tdm.aspx?lang=eng $>$. The rule amendments proposed by ICSID also currently aim to incorporate a provision at Rule 22 stating "[f]or purposes of completing the arbitrator declaration required by Rule 26(3)(b), a party shall file a written notice disclosing the name of any non-party from which that party, its affiliate or its representative has received funds or equivalent support for the pursuit or defense of the proceeding ('third-party funding')": International Centre for Settlement of Investment Disputes, "Proposals for Amendment of the ICSID 
matter of best practice, the ICCA-QMUL Report provided several recommendations relating to the use of TPF. In this regard, it recommended that:

A party and/or its representative should, on their own initiative, disclose the existence of a third-party funding arrangement and the identity of the funder to the arbitrators and the arbitral institution or appointing authority (if any), either as part of a first appearance or submission, or as soon as practicable after funding is provided or an arrangement to provide funding for the arbitration is entered into. ${ }^{152}$

Failing to disclose a funding agreement could result in all or some of a tribunal being in a conflict of interest, the attendant delays while such conflicts of interest are determined, a risk of additional costs if a member of the tribunal needs to be removed and proceedings repeated, and an additional risk to the enforceability of the award. Thus, even where disclosure of funding is not strictly required by the applicable law, rules, or guidelines, a party in receipt of funding may want to disclose at least the identity of the funder to the tribunal to avoid any issues of tribunal independence and impartiality. This leads to the issue of whether, absent anything to the contrary that requires disclosure, the tribunal can order a party to disclose whether it is in receipt of TPF. ${ }^{153}$ In answer to this question, the ICCAQMUL Report set out as a principle that "[a]rbitrators and arbitral institutions have the authority to expressly request that the parties and their representatives disclose whether they are receiving support from a third-party funder and, if so, the identity of the funder." 154

Concurrent with the issues around disclosure of the existence of funding and the identity of the funder is the matter of whether the terms of the funding agreement ought to be disclosed. There is a growing body of public awards with respect to matters involving funding in investor-state arbitration, and tribunals in such cases have been willing to order the disclosure of the existence of funding, and the identity of the funder, along with in some cases even portions of the funding arrangement. ${ }^{155}$ In Muhammet Çap \& Sehil Inşaat Endustri ve Ticaret Ltd Sti v. Turkmenistan, the ICSID tribunal directed the disclosure of the identity of the claimant's funder along with the LFA. ${ }^{156}$ This action was rooted in its inherent power to control the integrity of the arbitration process. ${ }^{157}$ Central to the tribunal's decision were "ensuring the integrity of the proceedings" and whether there was a potential conflict of interest with the tribunal as a result of the presence of funding. Additionally, the claimant did not deny the existence of a funder, and there was an allegation that notwithstanding the

Rules - Consolidated Rules” (2019) ICSID Working Paper \#2, vol 2, online: <icsid.worldbank.org/ en/Documents/VOL 2.pdf $>$.

152 ICCA-QMUL Report, supra note 4 at 81.

153 Nigel Blackaby et al, Redfern and Hunter on International Arbitration, 5th ed (Oxford: Oxford University Press, 2009) at 5.99.

154 ICCA-QMUL Report, supra note 4 at 81.

155 See also RSM Production Corp v Saint Lucia (2014), ICSID Case No ARB/12/10 (International Centre for Settlement of Investment Disputes), online: <italaw.com/sites/default/files/case-documents/ italaw3318.pdf> (decision on Saint Lucia's request for security for costs); EuroGas Inc v Slovakia (2015), ICSID Case No ARB/14/14 (International Centre for Settlement of Investment Disputes), online: $<$ italaw.com/sites/default/files/case-documents/italaw6272_0.pdf> (procedural order no 3). $\mathrm{ARB} / 12 / 6$ (International Centre for Settlement of Investment Disputes), online: <www.italaw.com/sites/ default/files/case-documents/italaw4350.pdf> (procedural order no 3) [Turkmenistan PO3]. Ibid at paras 6,13 . 
presence of a funder, certain costs owing to the party moving for disclosure had not been paid. ${ }^{158}$ In an earlier decision where the tribunal first refused the request for disclosure, it articulated five factors that might militate in favour of disclosure, depending on the circumstances:

(1) "[t]o avoid a conflict of interest for the arbitrator as a result of the third party funder"; 159

(2) "[f]or transparency and to identify the true party to the case"; 160

(3) "[f]or the Tribunal to fairly decide how costs should be allocated at the end of any arbitration"; 161

"[i]f there is an application for security for costs if requested"; ${ }^{162}$ and

"[t]o ensure that confidential information which may come out during the arbitral proceedings is not disclosed to parties with ulterior motives." 163

Whether disclosure of funding terms would be required, and so directed by a tribunal, would appear to depend on the circumstances of the case. Obligations on disclosure to the tribunal and directions for disclosure from the tribunal will fall to the disputing party; the tribunal has no jurisdiction over the funder.

Connected to the issue of conflicts of interest and disclosure of funding and LFAs is how the party seeking funding can communicate with the potential funder in light of constraints on disclosure and so as to not waive privilege and what confidentiality or privilege might exist over the funder's own internal records. ${ }^{164}$ Matters that proceed to international arbitration, in particular international commercial arbitration, are usually subject to some form of a confidentiality agreement. A confidentiality provision in the underlying agreement to arbitrate, a specific confidentiality agreement or protocol at the outset of a dispute, or the rules adopted by the parties may limit the ability of a disputing party to disclose information about the dispute to a potential or current funder. To overcome this concern, the parties would typically interpret a standard exception in a confidentiality clause allowing disclosure to necessary third-party advisors to also encompass third-party funders. Additionally, depending on the law for the arbitration there could be issues around privilege that, while relatively well-established for Canadian litigation and domestic arbitral matters, may not

Ibid at paras 9, 11. Another issue that is perhaps more prevalent in investor-state disputes is the need to know the true party to see if the claimed applicable treaty applies to the claim.

Muhammet Cap \& Sehil Inşaat Endustri ve Ticaret Ltd Sti v Turkmenistan (2014), ICSID Case No $\mathrm{ARB} / 12 / 6$ at para 50 (International Centre for Settlement of Investment Disputes), online: $<$ italaw.com/ sites/default/files/case-documents/italaw4163.pdf>.

Ibid.

Ibid.

Ibid. Funding may be a factor in applications for security for costs where a respondent alleges a need for security as a result of suspicions that the claimant will not be able to pay its costs if the respondent is successful, forcing the claimant to show it has the funds or reveal that it has secured funding with an LFA that will cover adverse costs awards or otherwise provide capital for the same.

Ibid.

There is little international guidance or consensus on the issue: see ICCA-QMUL Report, supra note 4 at $118-20$. 
apply to an international arbitration. The practice that has emerged is, similar with litigation, the disclosure of information to a funder under a confidentiality agreement, or non-disclosure agreement (NDA). Additionally, common interest privilege agreements can be used to attempt to maintain privilege over such communications. ${ }^{165}$

Funding may also be a factor in the ultimate award of costs. If the funded party is successful, it will likely have incurred some measure of costs to the funder and might want to claim the costs of funding as part of its expenses. Any costs award will depend on the specific law and rules at issue; however, there is at least one example of a tribunal directing costs for funding. In Essar Oilfield Services Ltd. v. Norsco Rig Management Pvt Ltd., ${ }^{166}$ a fairly recent case from the UK, the Court confirmed that recoverable "costs of the arbitration," 167 which the tribunal was empowered to award under the applicable legislation, could include costs for funding. The Court confirmed that the tribunal's full indemnity award of legal costs along with the costs incurred by the claimant for funding were owed by the unsuccessful respondent. ${ }^{168}$

In terms of enforcement, there has been some debate over whether a party who obtains funding in an international arbitration could be exposed to risk upon seeking enforcement of that award if the jurisdiction of enforcement were to take the view that such funding offended its "public policy." 169 In 2015, the IBA subcommittee on the Recognition and Enforcement of Arbitral Awards issued a Report that delved into recognition and enforcement issues globally. ${ }^{170}$ The Report found that "there is no uniformity" in how enforcing courts review for grounds of public policy and "the predominant trend is to limit review to a conformitycheck of the arbitral decision itself, not its reasons, with public policy as assessed in the country where enforcement is sought." ${ }^{171}$ In doing such reviews, there was at that time no reported Canadian court decision where enforcement was refused due to funding. ${ }^{172}$ With respect to Canada, public policy grounds were only successful in refusing enforcement in extreme cases and were very fact-specific. ${ }^{173}$ British Columbia's recent amendments to its

In particular with international arbitrations in foreign jurisdictions or subject to foreign substantive law, it would be prudent to carefully assess how one ought to communicate with a potential funder. See the discussion in Meriam N Alrashid, Jane Wessel \& John Laird, "Impact of Third Party Funding on Privilege in Litigation and International Arbitration” (2012) 6:2 Dispute Resolution Intl 101 at 109. Of note, the IBA Rules on the Taking of Evidence in International Arbitration do have some provisions respecting privilege that could also assist: International Bar Association, "IBA Rules on the Taking of Evidence in International Aribtration" (London: IBA, 2010), art 9, online: <www.ibanet.org/Document/ Default.aspx?DocumentUid=68336C49-4106-46BF-A1C6-A8F0880444DC>. [2016] EWHC 2361 (Comm) [Essar Oilfields]. Arbitration Act 1996 (UK), s 63(3).

The funding terms in this case required the claimant to repay to the funder either 300 percent of the funding provided, or 35 percent of the amount recovered: see Essar Oilfields, supra note 165 at para 5. See Alberta's International Commercial Arbitration Act, supra note 146, Schedule 2, art 34 (an arbitral award may be set aside by a court if the court finds that the award is in conflict with the public policy of the State).

IBA Subcommittee on Recognition and Enforcement of Arbitral Awards, "Report on the Public Policy Exception in the New York Convention" (London: IBA, 2015), online: <www.ibanet.org/Document/ Default.aspx?DocumentUid=C1AB4FF4-DA96-49D0-9AD0-AE20773AE07E $>$.

Ibid at 18 .

Craig Chiasson \& Kalie McCrystal, "IBA Sub-Committee on the Recognition and Enforcement of Awards - Public Policy in Canada" (London: IBA, 2015) at 6, online: <www.ibanet.org/Document/ Default.aspx?DocumentUid=637B2129-8F34-4634-B156-AFF65A4A2974>.

See in particular Banglar Progoti Ltd v Ranka Enterprises Inc, 2009 CanLII 16292 (Ont Sup Ct J) at paras 16-19 where the Court, in light of the decision in McIntyre, undertook an examination of the motive of the parties for funding as "[i]t is not conceded that champerty and maintenance are contrary to public policy. Similarly, it is not conceded that these torts apply to both court proceedings and arbitration" (at para 18). 
International Commercial Arbitration Act confirm that in that province, the existence of funding does not constitute a reason for which enforcement can be refused on public policy grounds. ${ }^{174}$

\section{B. Domestic Arbitration}

As of the time of writing, we are not aware of any reported decisions in Canada, either from courts or public arbitral awards, that discuss TPF in a Canadian domestic arbitration. Nor are we aware of any enforcement proceedings on a domestic arbitral award where a party had obtained TPF and such factored into enforcement proceedings. Similarly, domestic arbitral legislation in Canada is devoid of comment on TPF and two of the most often-turnedto institutional rules for domestic Canadian arbitrations, the ADR Institute of Canada Inc. Arbitration Rules ${ }^{175}$ (ADRIC Arbitration Rules) and the International Centre for Dispute Resolution Canada Arbitration Rules ${ }^{176}$ (ICDR Canada Arbitration Rules) do not purport to expressly regulate matters relating to the use of TPF. Notwithstanding this lack of express mention in Canadian domestic arbitral statutes, and lack of jurisprudence on point, if the domestic dispute is subject to the laws of Canada then, along with authority from international arbitration, existing jurisprudence on TPF from Canadian litigation is likely instructive.

The same considerations discussed for international arbitration on confidentiality, disclosure, and privilege will also factor into a domestic arbitration. With respect to confidentiality obligations, and whether a party seeking funding could disclose information to a potential funder, these will again require a careful review of the underlying agreement at issue between the parties, the agreement to arbitrate, and the rules or other applicable guidelines. Both the ADRIC Arbitration Rules and the ICDR Canada Rules, for example, have terms that would, subject to any other obligations, likely permit disclosure of materials by a party to a funder. ${ }^{177}$ Also, unlike international arbitration, a domestic arbitration in

RSBC 1996, c 233. The Act states that for purposes of refusing enforcement on grounds of being contrary to "the public policy in British Columbia," "third party funding for an arbitration is not contrary to" such public policy (ibid, s 36(3)). In this statute, third-party funding is defined to be "funding for the arbitration that is provided (a) to a party to the arbitration agreement by a person who is not a party to that agreement, and (b) in consideration of the person who provides the funding receiving a financial benefit if the funded party is successful in the arbitration" (ibid, s 36(4)).

175 See ADR Institute of Canada, "ADRIC Arbitration Rules," version 2 (Toronto: ADRIC, 2014), online: $<$ adric.ca/wp-content/uploads/2017/08/2016 ARBITRATION RULES Booklet 2016_Aug2017.pdf> [ADRIC Arbitration Rules]. International Centre for Dispute Resolution, "Canadian Dispute Resolution Procedures" (ICDR, 2015), online: <icdr.org/sites/default/files/document_repository/ICDR-Canada-Rules-English.pdf> [ICDR Canada Arbitration Rules].

177 The ADRIC Arbitration Rules, supra note 175, define "Confidential Information" quite broadly to include "the existence of an arbitration and the meetings, communications, Documents, evidence, awards, rulings, orders, and decisions of the Tribunal in respect of the arbitration" (s 1.2). Section 4.18.2 then contains a few clauses on privacy and confidentiality, chief among these that the parties are to keep confidential all Confidential Information unless "(a) required by a court; (b) necessary in connection with a judicial challenge to, or enforcement of, an award; or (c) otherwise required by law." Notably, section 4.18.4 expressly provides for a party to disclose Confidential Information to that party's "other advisor, or other person with a direct financial interest in the arbitration." Such is likely to permit ongoing discussions with a funder about the arbitration. However, it is questionable whether these rules, without more, would have any impact on confidentiality prior to an arbitration being commenced when a party is first exploring a potential claim that it may wish to bring. In the ICDR Canada Arbitration Rules, supra note 175, Article 37(2) on Confidentiality only purports to bind the arbitrator and the Administrator, not the parties. The Tribunal may, however, "make orders concerning the confidentiality of the arbitration or any matters in connection with the arbitration," and at such time as this type of an order is being discussed, a party with funding (or who is contemplating seeking funding) may want to 
Canada will likely have greater clarity on the protections afforded to communications between a party and the funder under laws of privilege. As discussed above with litigation, privilege over materials disclosed to a funder could likely be maintained through a combination of common interest privilege and litigation privilege.

Unless the parties to the arbitration are adopting or agreeing to conduct the proceeding under a set of rules or guidelines that mandate disclosure, ${ }^{178}$ there is currently no express established requirement in Canadian legislation for a party to a domestic arbitration to disclose that it has secured funding. Absent any directions on disclosure, the disputing party with the TPF arrangement could choose to stay silent about the matter until, if ever, it is compelled to disclose. It might not be until later in the proceedings, perhaps in response to an application for security for costs or at enforcement of an award, that a party is so compelled. Failing to disclose the existence of funding early on does, however, carry significant risk with respect to Tribunal conflicts of interest. As discussed above, this is reflected in the recommendations of the ICCA-QMUL Task Force. ${ }^{179}$ Thus, while disclosure of funding is not strictly required by domestic statutes or rules, a party in receipt of funding may want to disclose at least the identity of the funder to the tribunal to avoid any issues of tribunal independence and impartiality.

The authority of the arbitrator with respect to matters of funding is likely subject to a factspecific assessment in each matter. The tribunal has an inherent power to control its process, ${ }^{180}$ but its jurisdiction is limited to what is conferred by the parties. ${ }^{181}$ It is unlikely that the arbitration agreement would confer any jurisdiction to the tribunal over the funder. ${ }^{182}$ As a result, the tribunal could likely request that a party disclose the existence of a funder, or any "other person with a direct financial interest in the arbitration." 183 The Tribunal's authority to direct the disclosure of any portions of the LFA is also potentially quite complex, involving detailed assessments of the Tribunal's power to control the integrity of the process and the reasons for such disclosure. ${ }^{184}$ If the Tribunal has the authority to make an award of costs, whether the costs incurred by the funder can be recovered if the funded party is successful would also require a fact-specific analysis and examination of the funding structure and applicable law. ${ }^{185}$

either disclose such funding or attempt to ensure any resulting confidentiality order does not circumscribe their ability to disclose to the funder.

Such as the IBA Guidelines 2014 (see the discussion at supra note 151 and accompanying text).

ICCA-QMUL Report, supra note 4 at 14.

J Brian Casey, Arbitration Law of Canada: Practice and Procedure, 3rd ed (Huntington, NY: Juris, 2017) at 210-12. See also Arbitration Act, RSA 2000, c A-43, s 20.

Casey, ibid at 195.

Casey discusses six theories where non-signatories might be bound to an arbitration agreement, of which only perhaps a situation of assumption or assignment by the funder of the claim might lead to such a result. Even if such jurisdiction was granted, expressly in the LFA or otherwise, there are potential issues around joinder and consolidation that may need to be considered (ibid at 199).

ADRIC Arbitration Rules, supra note 175 at 4.18.4.

Turkmenistan PO3, supra note 156 at para 1; Casey, supra note 180 at 210-12.

Under section 53 of the Arbitration Act, supra note 179, a tribunal "may award the costs of an arbitration," and at subsection (3), such costs "consist of the parties' legal expenses, the fees and expenses of the arbitral tribunal and any other expenses related to the arbitration." Recall also the discussion around Do, supra note 82, where the Court refused to award the plaintiff's claimed interest for a loan for the litigation. This decision was, however, also impacted by what the Court viewed as double recovery and the provisions of the Alberta Rules of Court, supra note 72, as they apply to litigation. 


\section{ChOOSING A FUnder ANd Negotiating A FUNDING AGREEMENT}

\section{A. Choosing A Funder}

When parties enter into an LFA, they enter into a long-term business relationship between client, funder, and lawyer. It is thus important for a client to choose a reputable, wellcapitalized funder that they can function with in an ongoing business relationship.

Before entering into an LFA, a party seeking funding should conduct due diligence regarding the funder's financial ability to fund the litigation to its conclusion and to bear any adverse costs awards. If the funder is not financially sound, the client could be left facing significant, and unexpected, costs. Due diligence should also be conducted regarding the funder's previous experience and track record before the courts. It may also be appropriate to consider whether a funder has noted "bench strength" in the specialized area of the claim, if applicable. Most funders employ former litigators as frontline risk analysts and investment managers, and a funder with the correct expertise can add strategic value to the case as it progresses.

The party seeking funding should also be aware of, and attempt to align, the incentives of litigant and funder. When a funder's stake in the litigation is too high, or if the client has no "skin in the game," 186 it can sap the client's motivation to actively pursue the litigation. ${ }^{187}$ While it should go without saying, unfair or onerous terms in an LFA should be avoided. It is the lawyer's duty to protect his or her client's interests during the negotiation of an LFA. In any event, the chances of an unscrupulous funder attempting to insert extortionate terms is relatively small, as funding litigation is a risky and long-term investment, and it is in the funder's best interest to maintain a positive relationship with the plaintiff.

\section{B. Early Process ANd Due Diligence}

After executing the NDA, which is the first step in seeking funding, a funder and client typically begin negotiating the key financial terms of the deal, and often will enter into a term sheet before the funder undertakes the more detailed due diligence process. At this stage, claimants and their lawyers should expect to have a more robust, but still preliminary, conversation with the funder about the case. In general, the funder will conduct a preliminary review of the case theory and key evidence at a high level as a "stress test" of the case merits. A funder will also consider the anticipated funding amount sought compared to the quantum of damages to determine whether the matter meets the funder's basic parameters. Funders commonly require a realistic damages estimate that supports the level of investment (usually about eight to ten times the proposed funding amount in reasonably attainable damages). A funder will also consider collectability of damages and enforcement risk.

See Justice Perell's comments on incentivizing the litigant in Kinross, ibid. While this case was decided in the class action context (where this issue may be more significant) it also applies to third-party funding in general commercial litigation. 
If this initial review is fruitful, the funder will typically issue a term sheet that outlines the economic terms of the proposed investment, and provides for a due diligence period to fully assess the merits of the case and related issues. This will usually require a specified period of exclusivity for review. Funders require exclusivity, because the diligence process is timeconsuming and may require bringing on an outside expert to analyze the specific area of law at issue. Once initial commercial terms have been agreed upon, the funder will begin its full due diligence process.

Litigation funders put each potential investment through rigorous diligence, which may take a number of weeks or months. This is commonly known as the underwriting process. Given that a typical case might last two or more years and involve a multi-million dollar commitment, the funder's in-depth review is essential. This process includes meeting with the party seeking funding, reviewing relevant documents, and possibly hiring outside experts (especially if the case revolves around a highly specialized area of law). If a funder is satisfied that a case will meet its criteria, it will then recommend the case to its Investment Committee, which may be comprised of former litigators, judges, arbitrators, and senior members of the business. If the Investment Committee approves the recommendation, the parties enter a more detailed LFA.

\section{Negotiating the Funding Agreement}

The LFA is typically a long-form commercial agreement that will be negotiated between the parties in some detail. The LFA contains the matters detailed in Section IV above, including the financial terms on which the funder agrees to fund the claim and the priority of payments following a recovery of litigation proceeds, as well as the parties' other rights and responsibilities in relation to the claim, such as rights of termination, and dispute resolution between the parties.

If as part of the funding arrangement the lawyers have agreed to take on the case on partial contingency (as described in the "risk sharing" model above), then the lawyers will also be parties to the LFA, and the LFA may contain covenants on behalf of the lawyers that include reporting obligations to the funder. Any such lawyer covenants must be drafted so as not to interfere with the lawyers' duties to the client. It is important that a client obtain, or have the opportunity to obtain, independent legal advice on the LFA and it might be prudent to obtain this advice from individuals experienced in sophisticated financial transactional documents.

\section{CONCLUSION}

While the idea of a non-party to a dispute providing funding to advance that dispute may not be new, the TPF industry has undergone rapid and fundamental change in the past decade. Modern TPF has evolved from a niche tool used by impecunious litigants for advancing single cases to a multi-faceted industry that encompasses solutions ranging from BTE and ATE insurance to portfolio financing to the provision of working capital. TPF is also increasingly used by well-capitalized businesses as a method of risk and budget management by allowing them to pursue litigation off balance sheet while still retaining upside. Case law has shaped this evolution, giving a green light to the concept of TPF generally while setting parameters on the returns a funder may seek and the control a funder 
may exert. As TPF matures, participants should expect further rules and regulations to further shape the industry.

Energy industry actors in both business and legal capacities should be aware of the potential of TPF and the legal and ethical issues that surround it. Many disputes that commonly arise in the energy and oil and gas context lend themselves naturally to the classic "underfunded plaintiff" model of TPF. However, with the developing potential to access working capital, to finance portfolios of mixed claims, and to allocate M\&A transaction risk, TPF may have much broader application to the energy industry. 
[this page is intentionally blank] 